\title{
Development of real-time flood forecast model for vamsadhara river through hydrological approach
}

\author{
Arunima Mahapatra ${ }^{1^{*}}$, Vazeer Mahammood ${ }^{2}$ and K H V Durga Rao $^{3}$ \\ Assistant Professor, Dr. Lankapalli Bullayya College of Engineering, Visakhapatnam, A.P, India ${ }^{1}$ \\ Professor, Civil Engineering Department, Andhra University, Visakhapatnam, A.P, India ${ }^{2}$ \\ Flood Forecasting \& Hydrological Modeling Division, Water Resources Group, National Remote Sensing Centre \\ (NRSC), Hyderabad, A.P, India ${ }^{3}$
}

Received: 21-June-2021; Revised: 20-August-2021; Accepted: 25-August-2021

(C)2021 Arunima Mahapatra et al. This is an open access article distributed under the Creative Commons Attribution (CC BY)

License, which permits unrestricted use, distribution, and reproduction in any medium, provided the original work is properly cited.

\begin{abstract}
Hydrologic simulation of large river catchments, and the decision to choose a computerized model, is a complex job that necessitates a thorough knowledge of rainfall-runoff processes. While modeling involves proper estimation of direct surface runoff volume and peak discharge in a watershed. In the present study, a real-time flood forecasting model is developed using Hydrological Modelling System (HMS) to forecast floods and River Analysis System (RAS) to identify inundation areas in the Vamsadhara river basin located between Odisha and Andhra Pradesh in India. The flood prediction model is constructed using a simulation of spatial data. The approach includes a loss model to compute infiltration loss, a transform model to simulate runoff rate, and a Muskingum routing method to route flow in a river along with model calibration, and validation with field data. Topographic and hydrologic parameters for each of 17 sub-basins are computed using Land Use, Land Cover $(L U L C)$. Muskingum parameters are also calculated. The hydrological model has been calibrated using the precipitation and gauge discharge data of the 2006 flood event. For validation of the modeling process, flood events in 2010 and 2013 at two Gunupur and Kashinagar gauge stations were chosen. The simulated peak discharges obtained are sufficiently accurate with observed data at both the gauge stations. The Nash-Sutcliffe efficiency (NSE) obtained for the calibration period are $0.78 \& 0.77$, which shows that model performance is good and accepted for simulation of streamflow. Similarly, the model performance for validation period is 0.81 \& 0.80 for 2010 flood event while for the 2013 flood event are 0.84 \& 0.82 indicating very good model performance. Overall, the study revealed that the HMS model could be employed for the calculation of surface runoff and flood forecasting in similar areas and conditions existing nearby catchments. Flood inundation maps generated with HEC-GeoRAS and Hydrologic Engineering Center-River Analysis System (HEC$R A S)$ for $1 D$ steady flow demonstrate the model's output. As a result, this would help in the effective monitoring of flood hazards and the sustainable management of watersheds.
\end{abstract}

Keywords

GIS, Flood forecast, DEM, Flood inundation map, HEC-HMS, HEC-GEORAS, HEC-RAS.

\section{Introduction}

River floods are usually caused by a combination of wind-driven flood surges, low barometric pressure, and massive waves colliding with high upstream river flows. These floods are known to be the most devastating natural hazards. In India, wide sectoral and regional variables impact country climate change adaptability [1]. According to Markus et al. [2] climate change effects in the catchment, this change in climate is the leading cause of floods, mostly due to deforestation, urbanization, etc.

\footnotetext{
*Author for correspondence
}

Statistics suggest that floods account for almost $15 \%$ of all deaths from natural disasters and that the economic damages caused by floods have been seen to surpass billions of dollars worldwide, not just in developed countries in Asia but also in the countries of the European Union [3].

The occurrence of catastrophic weather conditions in recent years has proven the need of realistic flood models, which function as early warning systems in severe storm situations, reducing economic damage. An early warning system comprises both structural and non-structural measures. While structural incorporates the physical construction of embankments, canals, and so on, non-structural 
initiatives include flood forecasting models that reduce flood risks $[4,5]$. Many countries have made modeling and forecasting such occurrences a top priority [6].

Hydrological Modelling System (HMS) developed by the United States Army Corps of Engineers (USACE) helps in simulating the hydrologic cycle of a dendritic watershed system [7]. This model is especially well adapted for simulating direct runoff, which incorporates (overland flow and interflow) and runoff volume, as well as routing to the outlet [8].

Infiltration loss (Loss model), Transform model, and Muskingum routing model are the three most important components in watershed management. The loss model is based on the Soil Conservation ServiceCurve Number (SCS-CN). The transformation of rainfall to direct runoff is based on SCS-Unit Hydrograph (UH). The channel routing of river flow based on the Muskingum routing method. This method has been successively used for several hydrological case studies $[9,10,11]$.

The Vamsadhara river basin flows east between Mahanadi and Godavari. Its catchment area is 10,830 $\mathrm{km}^{2}$, of which $8015 \mathrm{~km}^{2}$ is in Odisha and $2815 \mathrm{~km}^{2}$ is in Andhra Pradesh (SANDRP) [12]). Almost every year, severe cyclones and heavy rain cause flooding in the Vamsadhara River affecting both Orissa and Andhra Pradesh. Both states experienced devastating floods in 2001, 2003, 2006, 2008, 2011, 2013 (Phallin) \& 2019 (Fani). Rivers flowing downstream are primarily responsible for raising the risk of flooding and cause extreme flood events [13]. Andhra Pradesh lies downstream of the river basin, with districts like Guntur, Krishna, Srikakulam, and Vizianagaram is being extremely vulnerable.

Odisha's Rayagada, Ganjam, Kendrapada, and Jagatsinghpur districts are susceptible upstream. These flood disasters wiped out entire neighbourhoods or even towns, destroying a large portion of agricultural fields, and resulting in severe property and life loss. With the frequent occurrence of floods in Vamsadhara River, it's essential to develop and use event-based watershed model that explain precipitation-runoff processes, which have been a major focus of hydrological study and investigation for decades [14].

The most difficult aspect of analyzing the river basin is model selection, data availability, calculating the hydrological parameters of the watershed, and project budget. The decision to choose a model is a challenging and critical one for the success of the analysis is dependent on the accuracy of the results and the computer's processing speed. To date, however, no extensive hydrological investigations have been carried in most of the Vamsadhara River catchments. As a result, evaluating and predicting a flood risk has become a necessity to undertake a study on hydrologic simulations, and an effort is made to develop a suitable watershed model and classify flood-prone areas in the watershed.

The study's main objective is to produce flood hydrographs from real-time data at Gunupur and Kashinagar. Calibrate and validate the flood forecast model's peak discharges using Central Water Commission (CWC) data. A steady flow analysis of peak discharges was also done for selected flood events in 2006, 2010 and 2013.

\section{Literature review}

Remote sensing datasets from many satellites provide significant information not only for monitoring watersheds, but also for extracting input data, such as Land Use, Land Cover (LULC), Digital Elevation Model (DEM) etc. These geospatial data are utilized for land use mapping, ground water model, and flood risk assessment [15]. Geographic Information System (GIS) facilitates in the processing of Shuttle Radar Topography Mission (SRTM) DEM data used as input for rainfall runoff modeling in order to extract basin features for the Vamdsadhara River basin. Numerous researches have established that integrating GIS with Hydrologic Engineering Center (HEC)-GeoHMS enables the creation of a hydrological model [16, 17, 18]. Hydrological models provide a framework for forecasting and evaluating rainfall runoff processes.

The HMS components used in hydrological modeling systems range from lumped conceptual models to spatially distributed hydrological modeling techniques [8]. HEC-HMS is a lumped, event-based runoff model that may possibly simulate rainfall-runoff relationships within a basin [19, 20]. Event-based models are intended to simulate individual events, with a focus on infiltration and surface runoff, and they predict peak discharge and runoff volume. Many studies have demonstrated that event-based models outperform continuous models $[21,22]$.

The HMS is widely utilized in a variety of applications, like in the design of drainage systems quantifying the land-use effects on streamflow [23, 24]. Several studies have shown that hydrologic 
models can be used efficiently for flood forecasting and simulating rainfall-runoff processes in various basins around the world [25-31]. Flood hydrographs obtained by HEC-HMS is used directly in various geographical areas to solve a high level of complexity, including large river basins, flood warning system, and natural watershed runoff [32].

A study on flood damage reduction indicates measuring the increased volume of runoff for proposed land-use changes in a watershed owing to floods [33-35].

Previous research has found that the HEC-HMS model can simulate direct runoff with a number of distinct combinations of loss methods, transform methods, and routing strategies [36].

Halwatura and Najim [37] applied the HMS model to the Attanagalu Oya river basin in Sri Lanka for simulation and validation. Finally, they concluded that Snyder's UH was the best transformation approach.

Azam et al. [38] obtained acceptable results using the modified SCS loss method and the Clarke Unit hydrograph to simulate peak runoff, whereas $[39,40]$ simulated runoff using the SCS-CN technique and the SCS UH method to estimate losses and direct runoff.

Vaishnava [41] examined several catchments of the Mahanadi basin, Seonath, and Jonk. The simulation findings of rainfall-runoff processes obtained for the Jonk catchment were preferable to those produced for the Seonath catchment.

The hydrologic model can further be utilized in floodplain studies which generate water surface profiles and flood inundation maps for flood-prone areas. [42-44] investigated steady flow analysis, i.e., river channel behavior, and found that the Hydrologic Engineering Center Analysis System (HEC-RAS) is an excellent tool for creating floodplain maps.

In $[45,46]$ investigated using both hydrologic and hydraulic modeling for estimating runoff from intense rainfall events, further flood risk and damages can be predicted and mitigated to some extent. Based on the review of the various literatures related to the application of HEC-HMS for hydrological modeling, it is concluded that this type of study provides a better response to analyzing future extreme conditions and serves as a tool for issuing early warnings during severe cyclonic rainfall in the basin. Large data needs, as well as a lack of clear guidance on the

1061 circumstances for their applicability, are a few key factors to consider while studying the river basin.

\section{Methods}

The HEC-HMS model is a physically and conceptually event-based model that is designed to simulate rainfall-runoff processes in a wide variety of geographic areas, from large river basin water supply and flood hydrology to small urban and natural watershed runoff [8]. Figure 1 illustrates the overall methodology for accomplishing hydrologic and hydraulic modeling for the current study. Using real time daily rainfall data, discharge data in every reach of the river are determined for the selected flood events in the years 2006, 2010 and 2013 in HEC-HMS 4.2.1. Comparison between computed and observed flows is determined at the gauge station Gunupur and Kashinagar.

River geometry such as stream centerline, Bank lines, cross-section cutlines, levees are digitized in HECGeoRAS. Further stream centerline attributes and cross section cutline attributes are generated to export the HEC-GeoRAS file data to HEC-RAS 5.0.4. The steady flow analysis of the peak discharges obtained in the river is generated for the selected flood events using HEC-RAS 5.0.4. Further the water surface profiles obtained are imported in HEC-GeoRAS to generate flood inundation mapping. Section 3.3 contains a brief overview of methods.

\subsection{Study area}

Vamsadhara basin as depicted in (Figure 2) lies between the Mahanadi and Godavari river basins in the eastern part of India between 180151 to 190551 N latitudes and 830201 to 840201 East Longitudes. It has five principal tributaries viz. Chaldea, Phalphalia, Ganguda (Harbhangi), Sannanadhi, and Mahendrathanaya; all are on the left side of the river [47].

The basin is influenced by the south-west monsoon during these five months (June to October), receiving around 84.6 percent of rainfall and occasional cyclones as a result of the emergence of a low pressure in the Bay of Bengal. The average annual rainfall of magnitude is $1400 \mathrm{~mm}$. Two barrages are falling on the river are Neradi barrage and Gotta barrage. Since 1891 more the 11 no. of severe cyclones have occurred on this river basin (Source: Disaster Management Dept. A.P). The above categorization of river basins indicates that the Vamsadhara river basin with such a large catchment area needs a flood response time in 
terms of weeks and reflects major seasonal meteorological conditions.

\subsection{Input data}

3.2.1 precipitation and river gauge discharge data A basic prerequisite for any hydrological model, including the HEC-HMS model, is data on rainfall amount and timing. The National Remote Sensing Centre (NRSC) in Hyderabad provided gridded rainfall data with a resolution of $0.25 \times 0.25$ degrees for the years 2001 to 2013 . The daily rainfall data have a spatial reference GCS_WGS_1984. To ensure the consistency of precipitation data, gridded raster data was converted into station rainfall using the zonal statistics mean method for 17 sub-basins that have been created within the catchment [48].

The Vamsadhara river basin is having two-level forecasts and one inflow forecast station i.e Kashinagar, Gunupur and Gotta (Source: Integrated Hydrological Data Handbook 2013) [49]. Gunupur and Kashinagar, located at a latitude and longitude of $180421 \mathrm{~N}$ and $830571 \mathrm{E}$, are the gauge stations considered for river discharge. The gauge discharge data are collected for the years 2006, 2010, and 2013 from CWC, Water Resources Department, Bhubaneswar, Odisha.

3.2.2 DEM and satellite data

The DEM with $30 \mathrm{~m} \times 30 \mathrm{~m}$ resolution is projected using Universal Transverse Mercator (UTM) zone 44; WGS 1984, and was acquired from SRTM from NRSC, Hyderabad. It takes as input, for preprocessing, basin processing, characteristics, and various hydrologic parameters in HEC-GeoHMS. Once the processing is completed mapping GeoHMS units to HMS units, background shapefile, and basin model file, meteorological model files are generated to export the file data from GeoHMS to HMS.

Bhuvan website provided Resourcesat-1, Linear Imaging Self Scanning Sensor (LISS-III) image of 302-2012 with a resolution of $23.5 \mathrm{~m}$ has been used to generate the river geometry and flood plains HECGeoRAS 10.2.

\subsubsection{Soil and LULC data}

The National Bureau of Soil Science \& Land Use Planning (NBSS\&LUP) provided the research region with soil data. Most of the soils in the river basin are identified as loamy, clayey, and clay soils which have low, medium, and high erosion properties respectively [50].

LULC chart was collected from NRSC, Hyderabad. It has been divided into eight classes of built-up/urban areas, cultivating land, current fallow, plantation, evergreen forest, deciduous forest wasteland, water bodies. LULC data are primarily required for the assigning of Curve Numbers (CN) to land areas for the computation of runoff and hydrological study.

3.2.4 Geology and slope data

The study area is part of the Achaeans' eastern ghats group, which is dominated by charnockites and kondalites on the left banks of the river basin and granite gneisses on the right bank [51]. The basin is narrow and undulated [52], with significant slope frequencies indicating rapid runoff in the northeast and the northwest region. The slope of the river basin has been grouped into five classes i.e., level, gentle, strong, moderate, and steep slopes [50].

\subsection{Methodology}

Runoff computations and execution phases in the HEC-HMS and HEC RAS model is shown in Figure 3.

3.3.1Rainfall-runoff model development

Basin Model: HEC-Geo HMS is used to create a basin model by DEM processing in ARC GIS 10.2 The processing includes DEM reconditioning, fill sinks, flow direction, stream definition, catchment delineation, drainage line delineation using $30 \mathrm{~m} * 30$ $\mathrm{m}$ resolution SRTM DEM. A total of 17 sub basins was generated for the present study. Delineation of the watershed into the appropriate number of subbasins is another critical job in modeling. According to Hromadka et al. [53] accuracy of the hydrological model increases, with the effect of watershed division. So to increase the model's overall accuracy, the catchment is divided into 17 sub-basins by different trials, and specified threshold values are used in the research area's watershed. The basin model with subbasins and basin features created in the form of a background map file is imported to HEC-HMS from the data derived by HEC-GeoHMS for model simulation. In HEC-HMS 4.2.1 each model runs combined with a basin model, meteorological model control specification and time series data. The basin model consists of hydrologic elements (sub-basins, junctions, reach) and drainage network of the catchment. While in meteorological model defines daily rainfall given as input. To control specification starting date, time and ending date time is scheduled for simulation. Real time series data for all meteorological elements are fed with gauge discharge data for calibration and simulation of the developed model. Figure 4 depicts the entire hydrological modeling with sub-basins, junctions, and reaches of the upper Vamsadhara river generated in HEC-HMS 4.2.1. 
International Journal of Advanced Technology and Engineering Exploration, Vol 8(81)

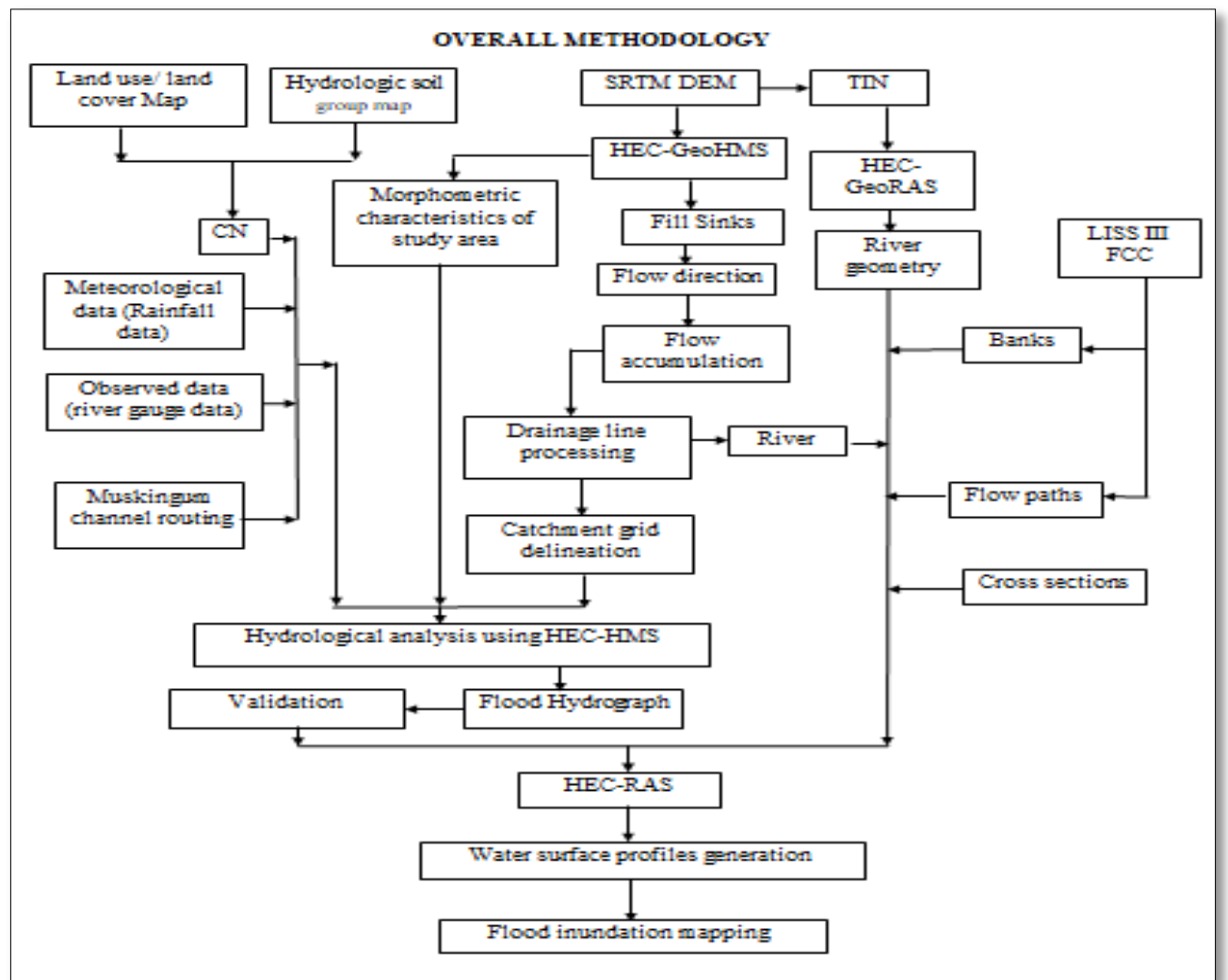

Figure 1 Methodology for modeling process

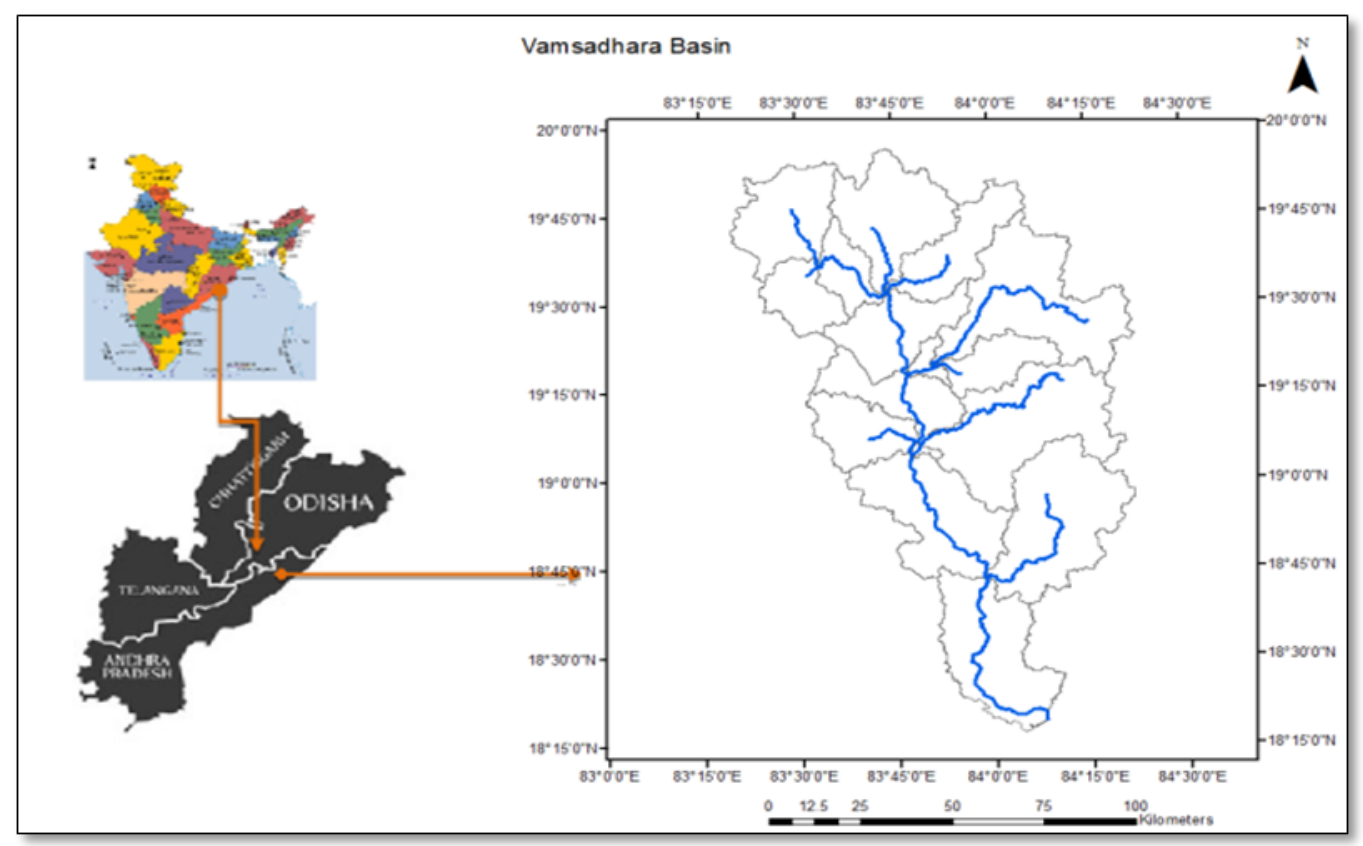

Figure 2 Vamsadhara basin: location map 
Arunima Mahapatra et al.

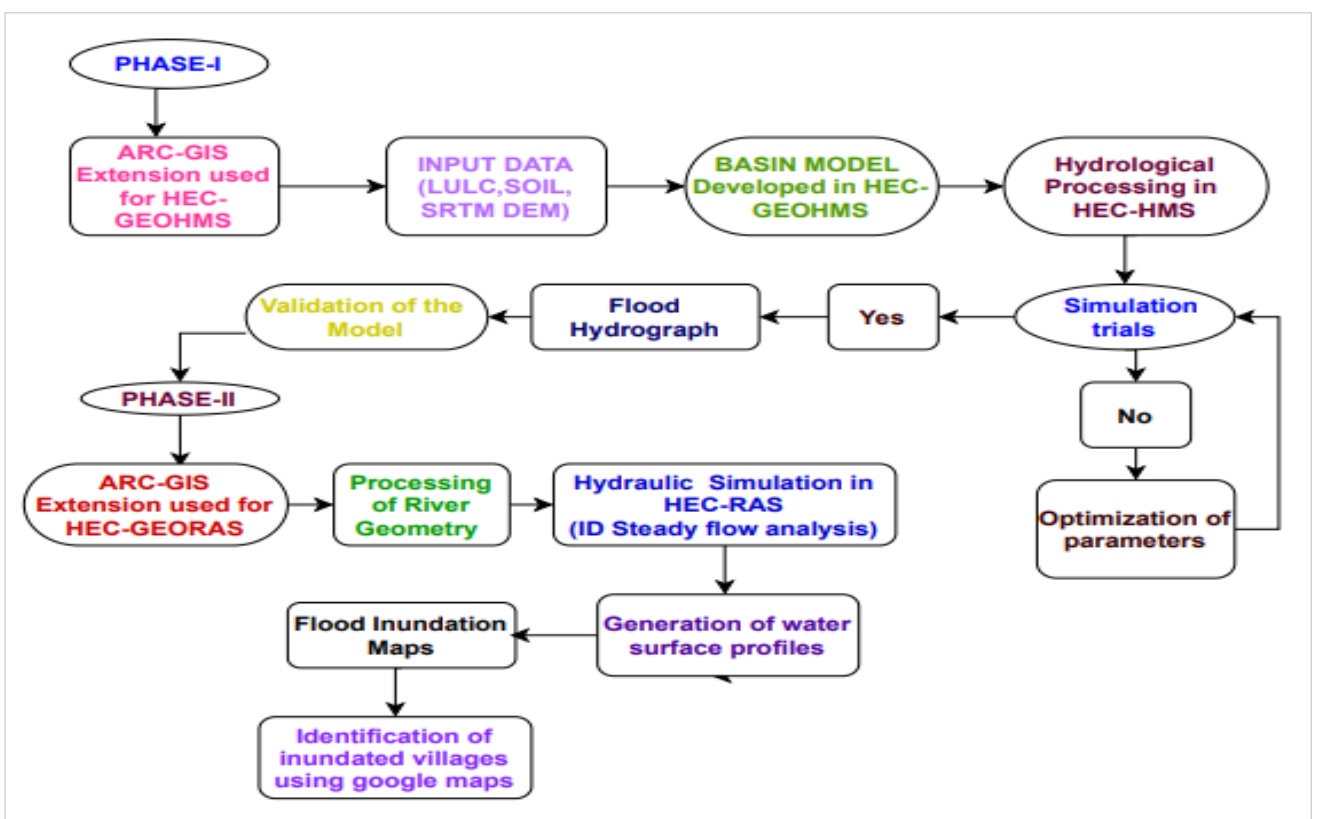

Figure 3 Block diagram showing execution phases in HEC-HMS \& HEC-RAS

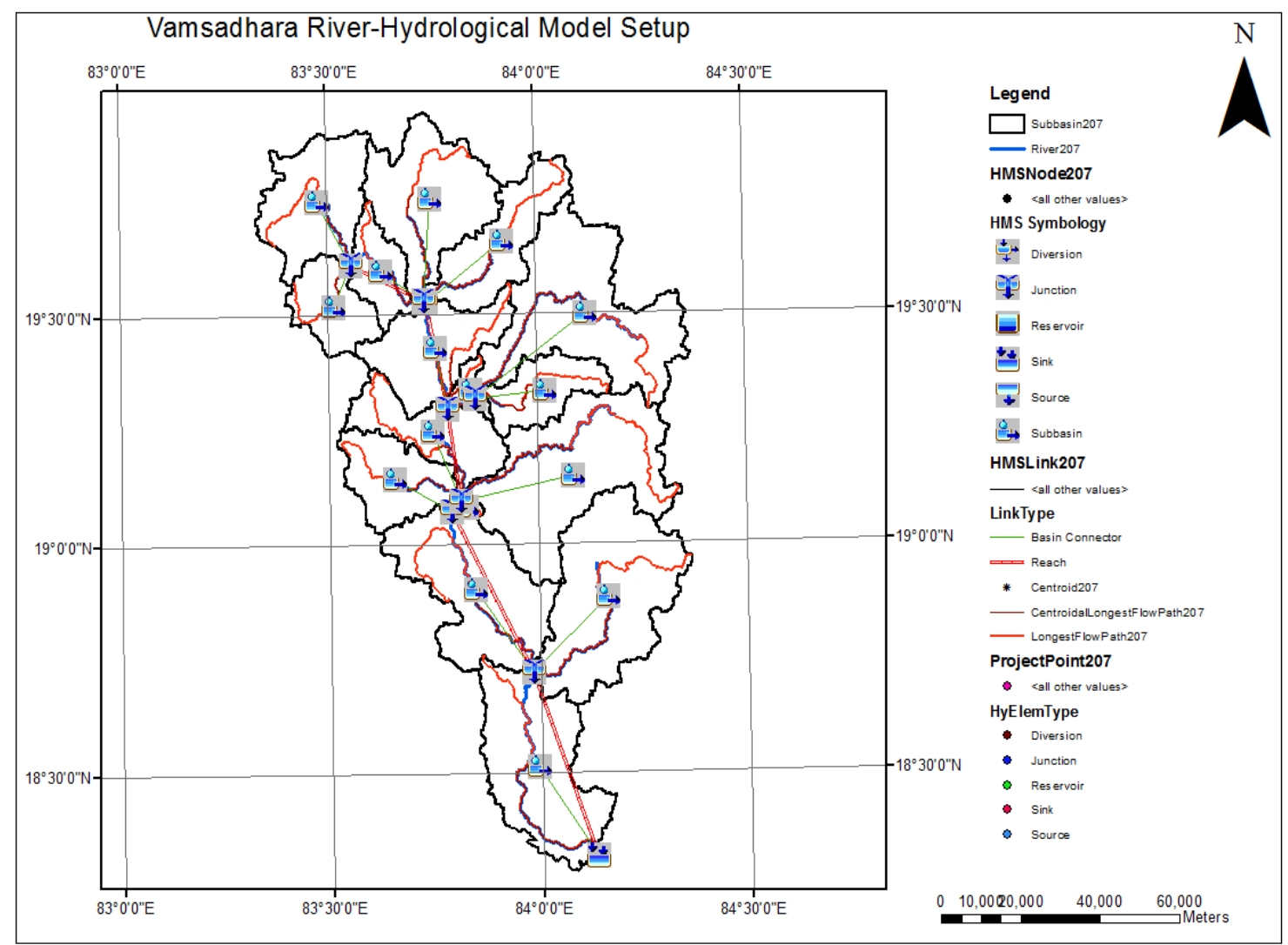

Figure 4 The hydrological modelling of Vamsadhara river 
There are several approaches to calculate the hydrological parameters required to run a model before model simulation in HEC-HMS. Three methods were chosen for the study area to convert rainfall to run off, the SCS-Curve number as a loss model, SCS-Unit Hydrograph, as a transform model for simulating direct runoff, and a Muskingum routing model for channel routing. These approaches were chosen based data availability, adaptability for similar hydrologic conditions, and study applicability. The next section discusses these methods in further detail:

\section{i) Loss model}

The loss models in HEC-HMS determine runoff volume by computing the volume of water that is intercepted, infiltrated, stored, evaporated and subtracting it from the precipitation [8]. The SCS developed the SCS-CN loss model was selected in this study to calculate the quantity of runoff from inputs such as rainfall and watershed coefficients for each sub-basin. The watershed coefficient is called the CN. It ranges from 0 to 100 . This approach was chosen because it is widely utilized in many applications and produces better results than the initial and the constant loss method [54].

McCuen [55] states that curve number is a simple conceptual method for computing direct runoff volume from a storm event, and is well supported by empirical data. It has been prepared by a combination of LULC and hydrological soil group data following the United States Department of Agriculture (USDA) standard table [56].

In $[21,57]$ emphasized the need of applying the loss model using SCS-CN for event based models.

\section{ii) Transform model}

The transform model, simulate the process of direct runoff of excess precipitation on a watershed. This excess precipitation is distributed uniformly spatially and is of constant intensity throughout a time interval [7]. A parametric UH model was proposed by the SCS 1972. The model is based on UH averages for a large number of watersheds calculated from gauged precipitation and runoff (HEC, 2000) [8]. SCS-UH was chosen because it is widely used and is more reliable in calculating runoff rate and produces better results than the Synder UH method [58]. Lag time is the only input for this method.

\section{iii) Muskingum flood routing model}

McCarthy [59] designed the Muskingum method, which is a common lumped flow routing approach. It was chosen for this study. The Muskingum routing technique utilizes a basic conservation of mass approach to traverse a stream reach [8].

Muskingum ( $\mathrm{K}$ : travel time) \& runoff coefficient (x) is the two parameters. This method has mostly been employed in the study of river engineering to compute hydrological routing parameters, since its introduction in 1930 [60], the Muskingum technique has been widely used. The data from the cross-section characteristics and flow conditions may be used to calculate travel time. Both of them are calibrated parameters, whereas $\mathrm{x}$ ranges from 0 to 0.5 . Typical streams have values of $\mathrm{x}=0.2$ to 0.3 . The routing parameters $\mathrm{K} \& \mathrm{x}$ values for eight reaches were calculated for the basin models are presented in Table 1. Calibrated routing parameter $\mathrm{K}$ and $\mathrm{x}$ evaluated were shown in Table 2.

Table 2 summarizes the HEC-HMS Curve Number values for all sub-basins. As mentioned in section 3.2.3, LULC is classified into eight classes for the current study, and $\mathrm{CN}$ values calculated range from 34.098 to 91.084, as shown in Table 3, indicating that the land used is in fair to good hydrologic condition with low to moderate runoff potential (NRCS, 2007).

Table 1 Muskingum parameters are considered for the run 2006

\begin{tabular}{llll}
\hline S. No. & Reach & Travel time $(\mathbf{K})$ & Runoff coefficient $(\mathbf{x})$ \\
\hline 1 & R40 & 0.05 & 0.2 \\
\hline 2 & R60 & 4.7 & 0.2 \\
\hline 3 & R90 & 4.46 & 0.2 \\
\hline 4 & R100 & 1.2 & 0.2 \\
\hline 5 & R110 & 3.95 & 0.2 \\
\hline 6 & R140 & 0.44 & 0.2 \\
\hline 7 & R150 & 7.2 & 0.2 \\
\hline 8 & R170 & 10.3 & 0.2 \\
\hline
\end{tabular}


Arunima Mahapatra et al.

Table 2 Calibrated parameter values of Vamsadhara Basin

\begin{tabular}{|c|c|c|c|c|c|c|c|}
\hline \multirow[t]{2}{*}{ S. No } & \multirow[t]{2}{*}{ Sub-basin } & \multirow{2}{*}{$\begin{array}{l}\text { Area } \\
(\mathbf{k m 2})\end{array}$} & \multirow{2}{*}{$\begin{array}{l}\text { Curve } \\
\text { before } \\
(\mathrm{CN})\end{array}$} & \multirow{2}{*}{$\begin{array}{r}\text { number } \\
\text { simulation }\end{array}$} & \multirow{2}{*}{$\begin{array}{l}\text { Optimal values } \\
\text { of }(\mathrm{CN})\end{array}$} & \multicolumn{2}{|c|}{ Muskingum Coefficient } \\
\hline & & & & & & $\mathbf{x}$ & $K(h r)$ \\
\hline 1 & W330 & 1016.6 & 45.35 & & 38.582 & 0.196 & 7.235 \\
\hline 2. & W320 & 1226.8 & 47.937 & & 40.784 & - & - \\
\hline 3. & W310 & 22.276 & 55.339 & & 47.081 & 0.2 & 0.46 \\
\hline 4. & W300 & 471.25 & 45.337 & & 38.571 & - & - \\
\hline 5. & W290 & 502.81 & 99 & & 91.084 & 0.196 & 3.969 \\
\hline 6. & W280 & 1312.0 & 37.063 & & 34.889 & - & - \\
\hline 7. & $\mathrm{~W} 270$ & 80.339 & 53.95 & & 49.636 & 0.2 & 2.7 \\
\hline 8. & W260 & 369.31 & 48.059 & & 44.216 & - & - \\
\hline 9. & W250 & 609.22 & 41.691 & & 38.357 & 0.196 & 5.0 \\
\hline 10. & $\mathrm{~W} 240$ & 0.5906 & 51 & & 46.921 & 0.3 & 0.05 \\
\hline 11. & W230 & 1289.5 & 37.063 & & 34.098 & - & - \\
\hline 12. & W220 & 363.88 & 46.305 & & 42.602 & - & - \\
\hline 13. & W210 & 584.01 & 41.072 & & 37.789 & - & - \\
\hline 14. & W200 & 288.90 & 45.736 & & 42.080 & 0.196 & 7.0 \\
\hline 15 & W190 & 845.80 & 41.589 & & 38.263 & - & - \\
\hline 16. & W180 & 681.85 & 70.798 & & 65.137 & - & - \\
\hline 17. & W340 & 1011.0 & 76.682 & & 76.682 & 0.2 & 10.3 \\
\hline
\end{tabular}

Table 3 Comparison results of simulated and observed flow for Vamsadhara Basin at Gunupur

\begin{tabular}{|c|c|c|c|c|c|}
\hline \multirow[t]{2}{*}{ Period } & \multirow[t]{2}{*}{ Date } & \multicolumn{2}{|c|}{ Simulated } & \multicolumn{2}{|c|}{ Observed } \\
\hline & & $\begin{array}{l}\text { Qs } \\
\left(\mathbf{m}^{3} / \mathbf{s e c}\right)\end{array}$ & $\begin{array}{l}\text { Vs } \\
\text { (MM) }\end{array}$ & $\begin{array}{l}\text { Qs } \\
\left(\mathrm{m}^{3} / \mathrm{sec}\right)\end{array}$ & $\begin{array}{l}\text { Vs } \\
\text { (MM) }\end{array}$ \\
\hline Calibration & $\begin{array}{l}15^{\text {th }} \text { Aug'06 } \\
\text { to } \\
15^{\text {th }} \text { Nov'06 }\end{array}$ & 3598.9 & 323.49 & 3127.2 & 406.11 \\
\hline Validation & $\begin{array}{l}15^{\text {th }} \text { Aug'10 } \\
\text { to } \\
15^{\text {th }} \text { Nov'10 }\end{array}$ & 756.8 & 195.92 & 700 & 197.42 \\
\hline Validation & $\begin{array}{l}15^{\text {th }} \text { Aug'13 } \\
\text { to } \\
15^{\text {th }} \text { Nov'13 }\end{array}$ & 1308.8 & 220.62 & 1211.4 & 251.15 \\
\hline
\end{tabular}

\subsubsection{Steady flow in RAS}

A river analysis system (HEC-RAS) is used for the current study to create water surface profiles. This system is capable of performing 1D steady flow analysis in natural or constructed channels and compute water surface profiles. This profile may be computed for various flow regimes such as subcritical, supercritical, and mixed flow regimes [61]. It may be computed from one cross-section to the next crosssection by solving the Energy equation with an iterative procedure called the standard step method. The Energy equation is written as follows:

$Z_{2}+Y_{2}+\frac{\alpha_{2} V_{2}^{2}}{2 g}=Z_{1}+Y_{1}+\frac{\alpha_{1} V_{1}^{2}}{2 g}+h_{e}$

(Courtesy: HEC-RAS 5.0.1)

$\mathrm{h}_{\mathrm{e}}=\mathrm{L} \bar{S}_{\mathrm{f}}+\mathrm{C}\left|\frac{\alpha_{2} \mathrm{~V}_{2}^{2}}{2 \mathrm{~g}}-\frac{\alpha_{1} \mathrm{~V}_{1}^{2}}{2 \mathrm{~g}}\right|$

$\frac{\mathrm{L}_{\text {lob }} \overline{\mathrm{Q}_{\mathrm{lob}}}+\mathrm{L}_{\mathrm{ch}} \overline{\mathrm{Q}_{\mathrm{ch}}}+\mathrm{L}_{\mathrm{rob}} \overline{\mathrm{Q}_{\mathrm{rob}}}}{\overline{\mathrm{Q}_{\mathrm{lob}}}+\overline{\mathrm{Q}_{\mathrm{ch}}}+\overline{\mathrm{Q}_{\mathrm{rob}}}}$

\subsection{Model performance}

The accuracy of the model is calculated by evaluating its performance prior to and post calibration, and during validation, using the following criteria proposed by Moriasi et al. [62]. In this study, NashSutcliffe Model Efficiency (NSE) and Coefficient of Determination $\left(\mathrm{R}^{2}\right)$ are utilized to evaluate the overall performance of the model.

The Nash-Sutcliffe Efficiency (E) criterion Nash and Sutcliffe [63] was recommended by an ASCE task committee in 1993. $\mathrm{E}$ is a positive integer in the range 0 to 1 , with $E$ equal to one being the optimum value. While values between zero and one are generally considered to be acceptable limits of performance, values less than or equal to zero implies that the observed discharge is a better indicator than the computed discharge, shows that the model performs insufficient. 
$\mathrm{NS} E=1-\left[\frac{\sum_{i=1}^{M}\left(m_{o b s, i}-m_{\text {sim }, i}\right)^{2}}{\sum_{i=1}^{M}\left(m_{o b s, i}-m_{\text {mean }}\right)^{2}}\right]$

$\mathrm{R}^{2}$ describes the ratio of variance and how the simulated data correlates with the observed values of data in the model.

$R S R=\frac{\sqrt{\sum_{i=1}^{M}\left(m_{o b s, i}-m_{\text {sim }, i}\right)^{2}}}{\sqrt{\sum_{i=1}^{M}\left(m_{o b s, i}-m_{\text {mean }}\right)^{2}}}$

\section{Results}

\subsection{Simulation of the model}

The hydraulic parameters that are primarily important for the model's good performance are calculated during the model's simulation of the flood event of 2006. Initial loss, CN, basin lag time, travel time (k), and runoff coefficient $\mathrm{x}$ are some of the most significant parameters in the model. The $\mathrm{CN}$, $\mathrm{k}$, initial loss, and lag time are identified as major sensitive parameters based on several parameter sensitivity investigations [54, 64]. Among the four sensitive ones, curve number and lag time can be computed in the ARC GIS 10.2 in GeoHEC-HMS component (USACE), and thus travel time (k) and initial loss become an emphasis for calibrating the model among the four sensitive ones. The initial loss is not taken into account in this study, and the remaining parameter, $\mathrm{k}$, the flood travel time along the channel, is calibrated in the HEC-HMS system using the trial-and-error approach [65]. The hydrologic order from upstream of the basin to the outlet includes reaches R40, R60 \& R90 i.e., Kutraguda to Gudari covering a distance of 60 km (CWC, Bhubaneswar), reaches R100, R110, R140 flows from Gudari to Gunupur covering a distance of $40 \mathrm{~km}$ (flood forecasting stations CWC, Bhubaneswar), while R150 flows from Gunupur to Kashinagar covers a distance of $37 \mathrm{~km}$ (gauge stations of the study area) and downstream of the basin is continued with R170 from Kashinagar to Gotta is 27.7 $\mathrm{km}$. The Muskingum parameters K \& $\mathrm{x}$ calculated for the run 2006 are shown the Table 1

\subsection{Model calibration and validation}

Parameters are finely tuned until the model's output is consistent with historical data, this tuning is nothing but adjusting of model parameter values which is known as calibration. By calibrating parameters and evaluating until the model hydrographs match and fit well between computed and observed flows. Cunderlik and Simonovic [66]. The hydrological developed model for this study is simulated, and the optimal parameter values evaluated are presented in Table 2. Calibration is performed using the optimal parameter values from Table 2, i.e., from 15th August to 15 th November 2006 for 90 days utilizing daily rainfall data, gauge discharge data, and stage data.

The observed discharge data are taken as input at Gunupur and Kashinagar gauges which are located on J91 and J81 in the sub-basin. The computed hydrograph is compared to the observed hydrograph at Gunupur and Kashinagar gauge station. The observed data closely match with the output simulated hydrographs generated after the simulation run for the 2006 flood event. The results tabulated for model calibration are listed in Table 3 for Gunupur and in Table 4 for Kashinagar.

In Table 3 the calculated peak discharge at Gunupur is $3598.9 \mathrm{~m}^{3} / \mathrm{sec}$ is slightly higher than the observed peak, flood hydrographs exactly match with observed peak discharge as shown in Figure 5(a). The total volume is underestimated and peak flow is overestimated than observed flow. Also, as shown in Table 4 the calculated peak discharge at Kashinagar is $3883.9 \mathrm{~m}^{3} / \mathrm{sec}$ is slightly higher than the observed peak with a discharge of $3830.3 \mathrm{~m}^{3} / \mathrm{sec}$, flood hydrographs exactly match with observed peak discharge as shown in Figure 5(b).

Table 4 Comparison results of simulated and observed flow for Vamsadhara Basin at Kashinagar

\begin{tabular}{|c|c|c|c|c|c|}
\hline \multirow[t]{2}{*}{ Period } & \multirow[t]{2}{*}{ Date } & \multirow{2}{*}{$\begin{array}{c}\text { Simulated } \\
\text { Qs } \\
\left(\mathrm{m}^{3} / \mathrm{sec}\right)\end{array}$} & \multicolumn{3}{|c|}{ Observed } \\
\hline & & & $\begin{array}{c}\text { Vs } \\
(\mathbf{M M})\end{array}$ & $\begin{array}{c}\mathrm{Qs} \\
\left(\mathrm{m}^{3} / \mathrm{sec}\right)\end{array}$ & $\begin{array}{c}\text { Vs } \\
(\mathbf{M M})\end{array}$ \\
\hline Calibration & $\begin{array}{l}15^{\text {th }} \text { Aug '06 to } \\
15^{\text {th }} \text { Nov }\end{array}$ & 3883.9 & 261.70 & 3830.3 & 347.86 \\
\hline Validation & $\begin{array}{l}15^{\text {th }} \text { Aug ' } 10 \text { to } \\
15^{\text {th }} \text { Nov' } 10\end{array}$ & 856.9 & 197.39 & 750 & 186.39 \\
\hline Validation & $\begin{array}{l}15^{\text {th }} \text { Aug'13 to } \\
15^{\text {th }} \text { Nov'13 }\end{array}$ & 2033.9 & 231.33 & 1998.9 & 238.91 \\
\hline
\end{tabular}


The calibrated model parameters are then tested for another set of historic field observations i.e., for the flood event 2010 \& 2013 for validation. In this process, if the calibrated parameters do not match with the historical data, the parameters must be refined using multiple trials.

The validation results computed are shown in Table 3 and Table 4. From Table 3 at Gunupur the computed peak discharge obtained is $756.8 \mathrm{~m}^{3} / \mathrm{sec} \& 1308.8$ $\mathrm{m}^{3} / \mathrm{sec}$ which are slightly higher than the observed peak for the flood events 2010 and 2013, flood hydrographs representing the following flood events are shown in Figure 6(a) \& Figure 7(a). The total volume is nearly matched with the observed volume as shown in Table 3.

Similarly, from Table 4 at Gunupur the computed peak discharge obtained is $856.9 \mathrm{~m}^{3} / \mathrm{sec} \& 2033.9 \mathrm{~m}^{3} / \mathrm{sec}$ which are slightly higher than the observed peak for the flood events 2010 and 2013, flood hydrographs representatives for the following flood events are shown in Figure $6(b)$ and Figure $7(b)$. The total volume is nearly matched with the observed volume as shown in Table 4. The results calculated show that the model calibrated and validated illustrates a close agreement with computed and observed hydrographs in terms of timing of peak, peak flow, and volume of flow. The relative percent errors between the observed and simulated values obtained found to be below $\pm 20 \%$ acceptance level [67].

\subsection{Processing of river geometry}

ARC GIS 10.2 is used to analyze the DEM and produce a Triangulated Irregular Network (TIN). River Cross-Sections, Stream Centerlines, Stream Bank Lines, and Flow Lines, as well as other river geometry information, are generated and digitized using the TIN in the HEC-GeoRAS model. For Steady Flow Analysis, the geometry data collected from TIN are transferred to HEC-RAS. Manning's roughness coefficient is assigned to all river stations in the catchment after the cross-section is checked and the geometry is adjusted.

Manning's roughness coefficient (n) often ranges between 0.030 and 0.050 in thick forest areas. The analysis used a value of 0.035 . The peak discharge in each reach of the river has been provided as flow data for profiles PF 2006, PF 2010, and PF 2013, which represent the discharges from selected flood events in 2006, 2010, and 2013. The water surface profiles for PF 2006, PF 2010, and PF 2013 are created using subcritical flow as the flow condition. HEC-RAS exports the produced water surface profiles to HECGeoRAS together with the modified geometry. Water surface profiles and flood inundation maps created in Arc GIS10.2 using RAS Mapping Tools are displayed in Figure 11. The villages flooded in Andhra Pradesh state in 2006 are depicted in Figure 12. The following Table 5 and Table 6 details the villages that were impacted by the 2006 and 2013 floods.

\section{Discussions}

As illustrated in Figures 5 show graphs comparing observed and simulated flow at both Gunupur and Kashinagar gauge stations for the calibrated year of 2006. The observed flow recorded at gauge stations at the respective junctions (J91, J81) is represented by the black dotted lines The simulated outflow at the junction is represented by the blue solid line. The stage data for that junction is indicated by the yellow dotted line. Figure 5(a) shows that the calculated hydrograph overestimates peak discharge; the computed peak is $3598.9 \mathrm{~m}^{3} / \mathrm{sec}$, whereas the observed peak discharge is $3127.2 \mathrm{~m}^{3} / \mathrm{sec}$, a variance of approximately 400 $\mathrm{m}^{3} / \mathrm{sec}$; nevertheless, the graph at Gunupur matches the historical data well. Figure 5(b) clearly shows that the calculated hydrograph overestimates the peak discharge, with a computed peak discharge of 3883.9 $\mathrm{m}^{3} / \mathrm{sec}$ compared to observed discharge 3830.3 $\mathrm{m}^{3} / \mathrm{sec}$, a percent variation of less than $1.4 \%$ that is acceptable.

The model was verified at both Gunupur and Kashinagar discharge stations during the flood's event of 2010 and 2013. Figure 6 shows validation period hydrographs for 2010, whereas Figure 7 shows validation period hydrographs for 2013. The calculated flow pattern resembles the observed flow pattern quite closely. From Figure 6(a) in 2010, the estimated peak discharge in Gunupur was 756.8 $\mathrm{m}^{3} / \mathrm{sec}$, whereas the observed flow was $700 \mathrm{~m}^{3} / \mathrm{sec}$, a variance of 50 cumecs that is negligible. Similarly, as shown in Figure 6(b), the estimated peak discharge at Kashinagar gauge stations is $856 \mathrm{~m}^{3} / \mathrm{sec}$, with a range of 100 cumecs, which is acceptable.

Figures 7(a) \&7(b) shows the calculated flood discharges during the 2013 cyclonic storm at gauge stations Gunupur and Kashinagar are $1308.8 \mathrm{~m}^{3} / \mathrm{sec}$ and $2033.9 \mathrm{~m}^{3} / \mathrm{sec}$, respectively, but the observed flows are $1211.4 \mathrm{~m}^{3} / \mathrm{sec}$ and $1998.9 \mathrm{~m}^{3} / \mathrm{sec}$. The variation at the upstream gauge station, J91, is higher than that at the downstream junction, J81 that may be owing to the travel time ' $\mathrm{K}$ ' taken from all upstream reaches. As this simulated hydrograph generated corresponds extremely well with the observed 
hydrograph, the Muskingum parameters $\mathrm{K}$ and $\mathrm{x}$ computed may be considered accurate.

The model performance was further computed using NSE [NASH, SUTCLIFFE 1970], between simulated and observed flow given by the equation (1). Figure 8 shows the scatter plot of the calibrated year, 2006 at J91 \& J81 with an NSE value of $0.786 \& 0.773$ at Gunupur \& Kashinagar gauge station. According to Moriasi et al. [62], E values obtained for calibrated model greater than 0.75 are considered to be good. $\mathrm{R}^{2}$ calculated given by the equation (2). The range of $R^{2}$ lies from $0-1$ where 0 is unacceptable i.e., lesser value indicates high error variance, but values greater than 0.5 are acceptable Van Liew [62]. The $\mathrm{R}^{2}$ values obtained for the model are $0.703 \& 0.707$; Since $\mathrm{R}^{2}$ values are greater than 0.5 are considered acceptable. Figures 9, 10 shows the scatter plot for the validated years, $2010 \& 2013$, with an NSE value of $0.812 \&$ 0.801 where as $R^{2}$ values are $0.729 \& 0.758$. NSE value is $0.843 \& 0.823$ along with $R^{2}$ value $0.707 \&$ 0.731 for the flood event 2013. The overall performance rating of the model validated has been found to be satisfactory indicating very good model performance. Figure 11 depicts the water surface profiles and flood inundation maps created in Arc GIS10.2 using RAS Mapping Tools. The villages flooded in Andhra Pradesh state in 2006 are depicted in Figure 12. Most of the villages are located in the downstream area of the sub-basin. The following Table 5 and Table 6 details the villages of Srikakulam district that were impacted by the 2006 and 2013 floods.

\subsection{Limitations}

Although acquiring high resolution DEM as the input data is so expensive, used SRTM 30m data as input to our model to decrease project costs. $30 \mathrm{~m}$ resolution is extremely low for achieving high accuracy results. Data such as rainfall and river cross-section data necessitate extensive fieldwork, which aid in enhancing the model's accuracy.

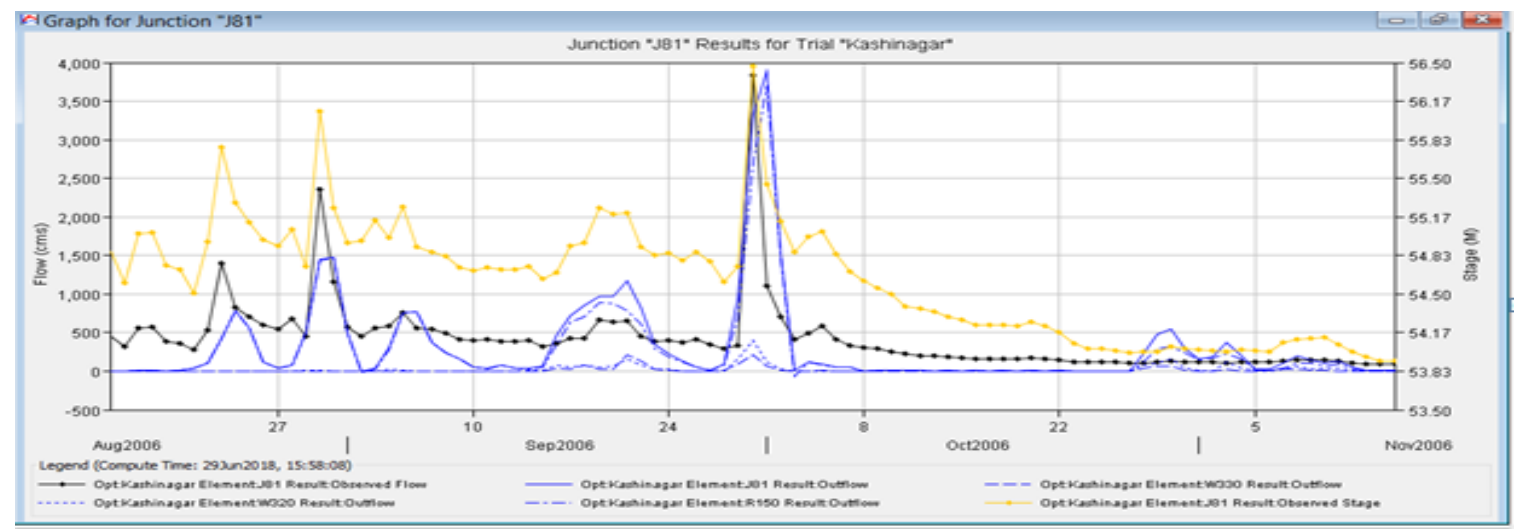

(a)

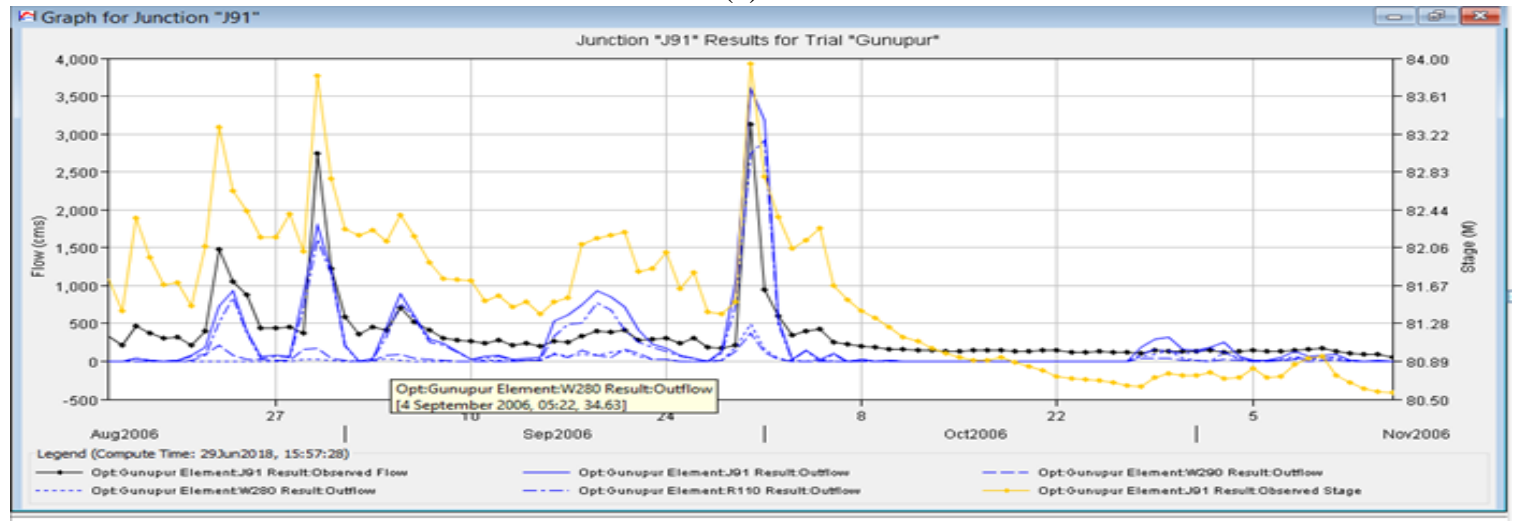

(b)

Figure 5 Observed \& Simulated discharge of Vamsadhara River for the selected flood event 2006 (a) Aug-Nov 2006; Gunupur (b) Aug -Nov 2006; Kashinagar 
Arunima Mahapatra et al.

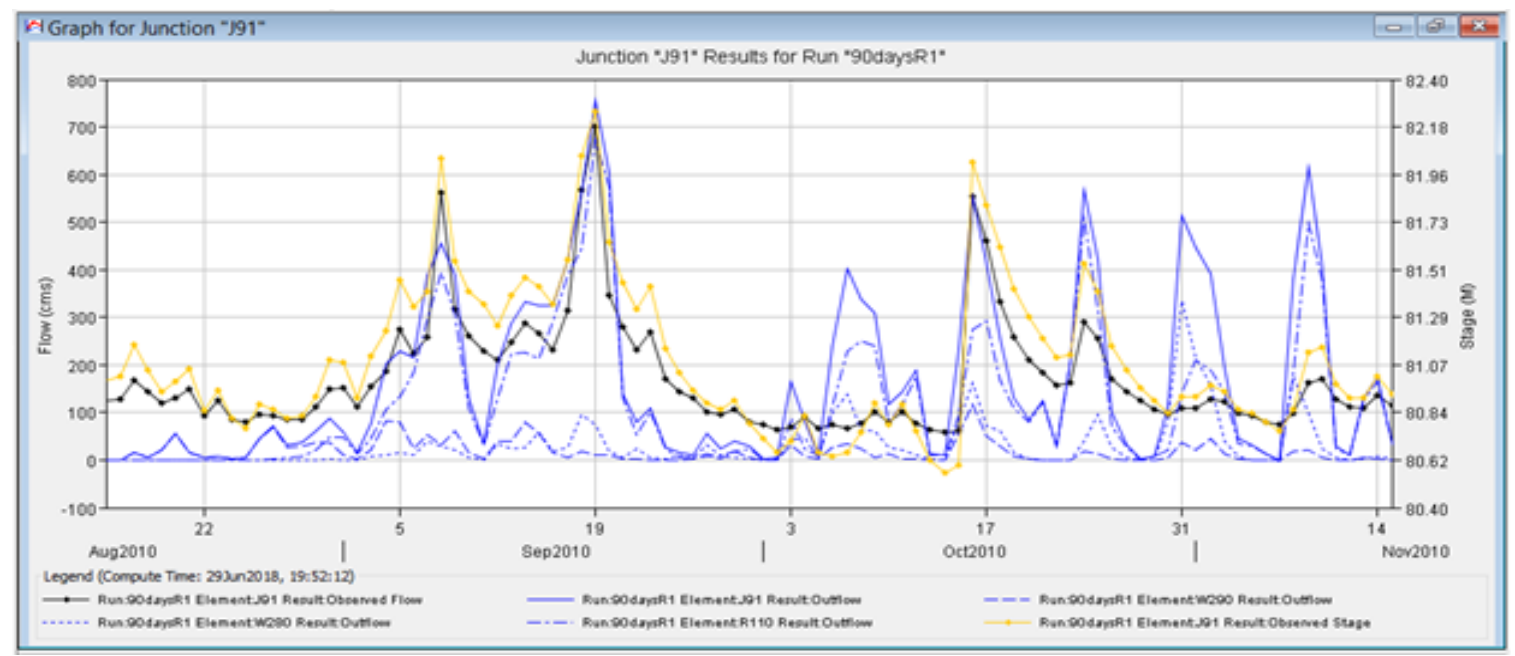

(a)

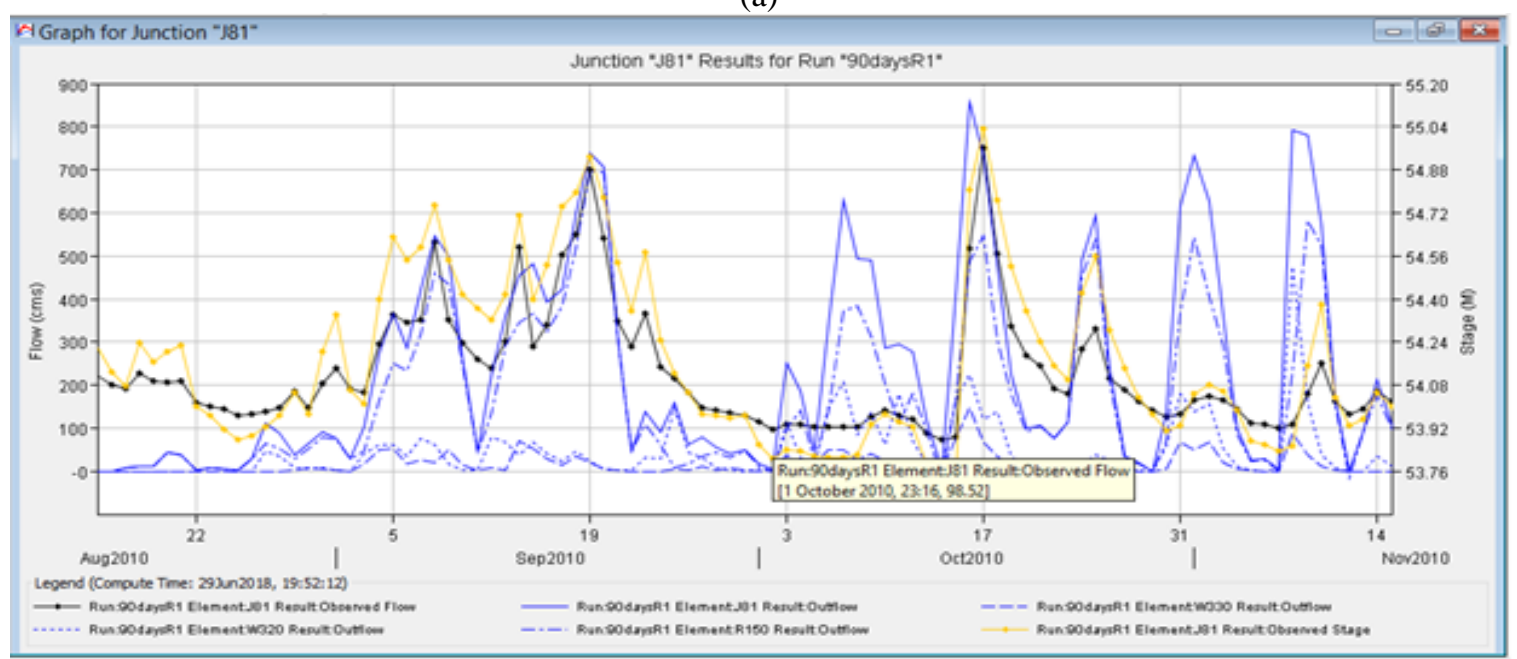

(b)

Figure 6 Observed \& Simulated discharge of Vamsadhara River for the selected flood event 2010 (a) Aug-Nov 2010; Gunupur (b) Aug -Nov 2010; Kashinagar (2010)

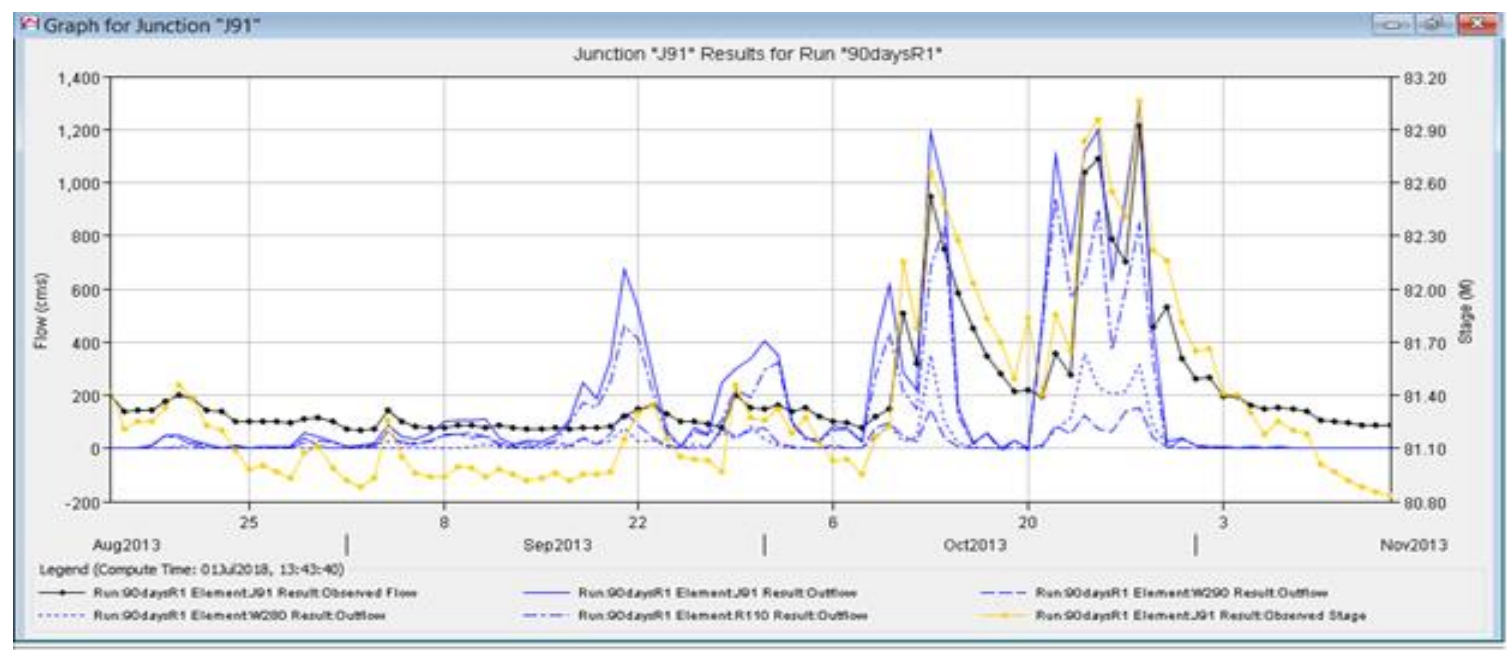

(a) 
International Journal of Advanced Technology and Engineering Exploration, Vol 8(81)

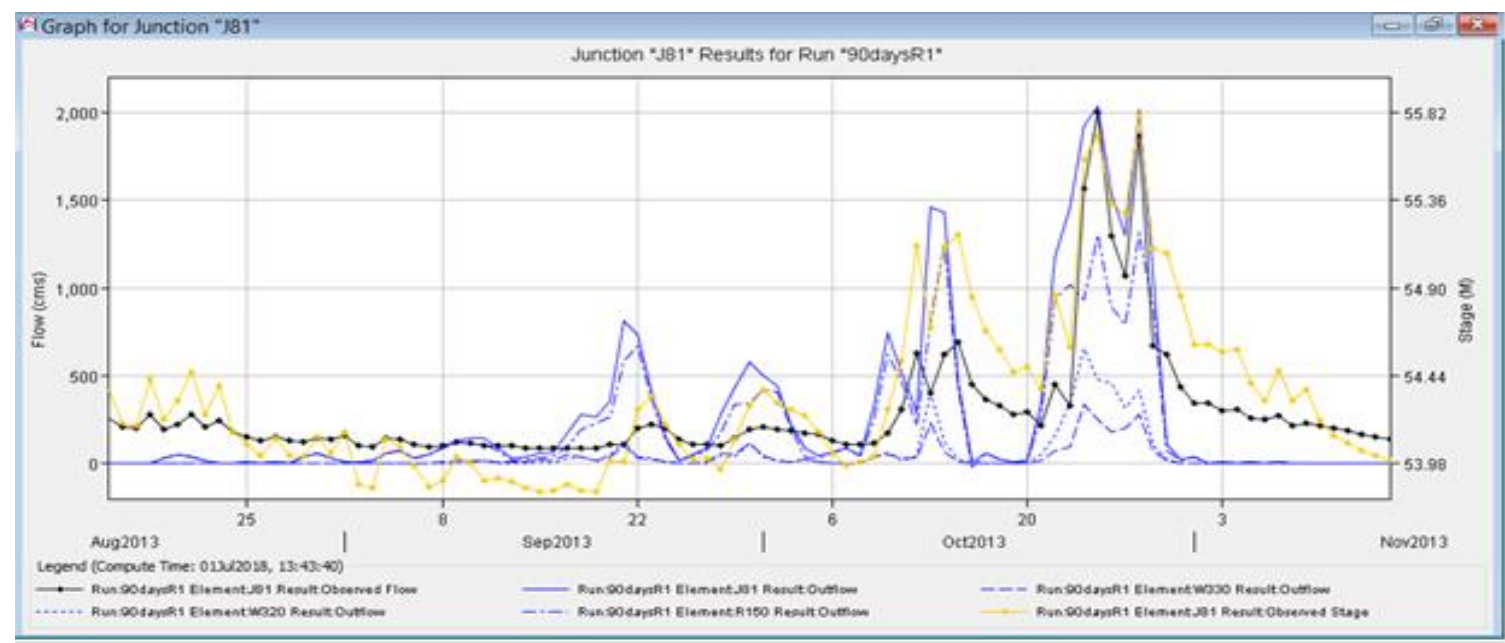

(b)

Figure 7 Observed \& Simulated discharge of Vamsadhara River for the selected flood event 2010 (a) Aug-Nov 2013; Gunupur (b) Aug -Nov 2013; Kashinagar

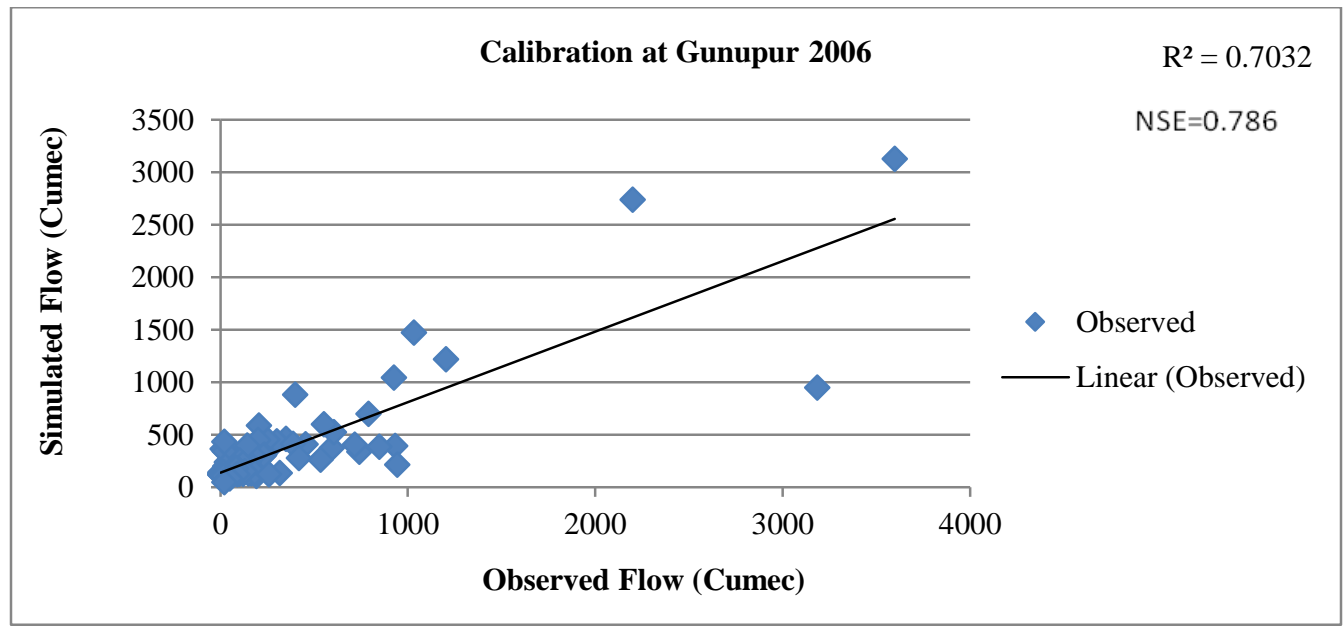

(a)

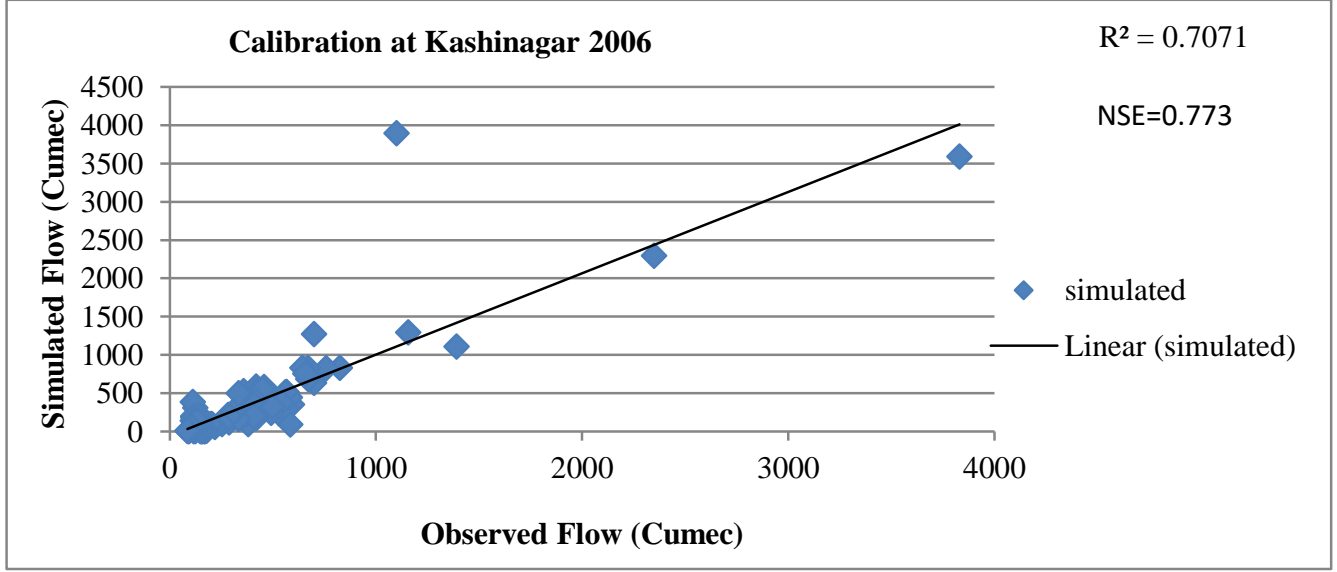

(b)

Figure 8 Scatter plot comparison between simulated \& observed flow for calibrated year 2006 for Vamsadhara river (a) At Gunupur gauge station (b) At Kashinagar gauge station 
Arunima Mahapatra et al.

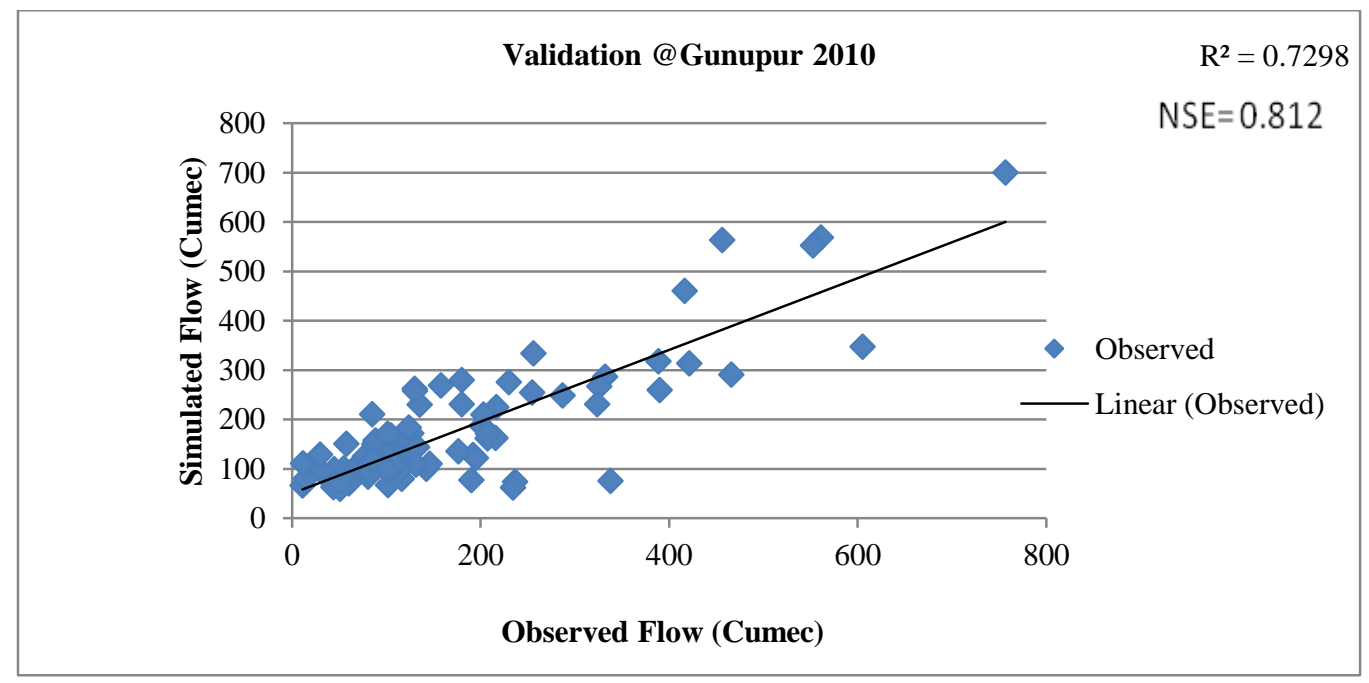

(a)

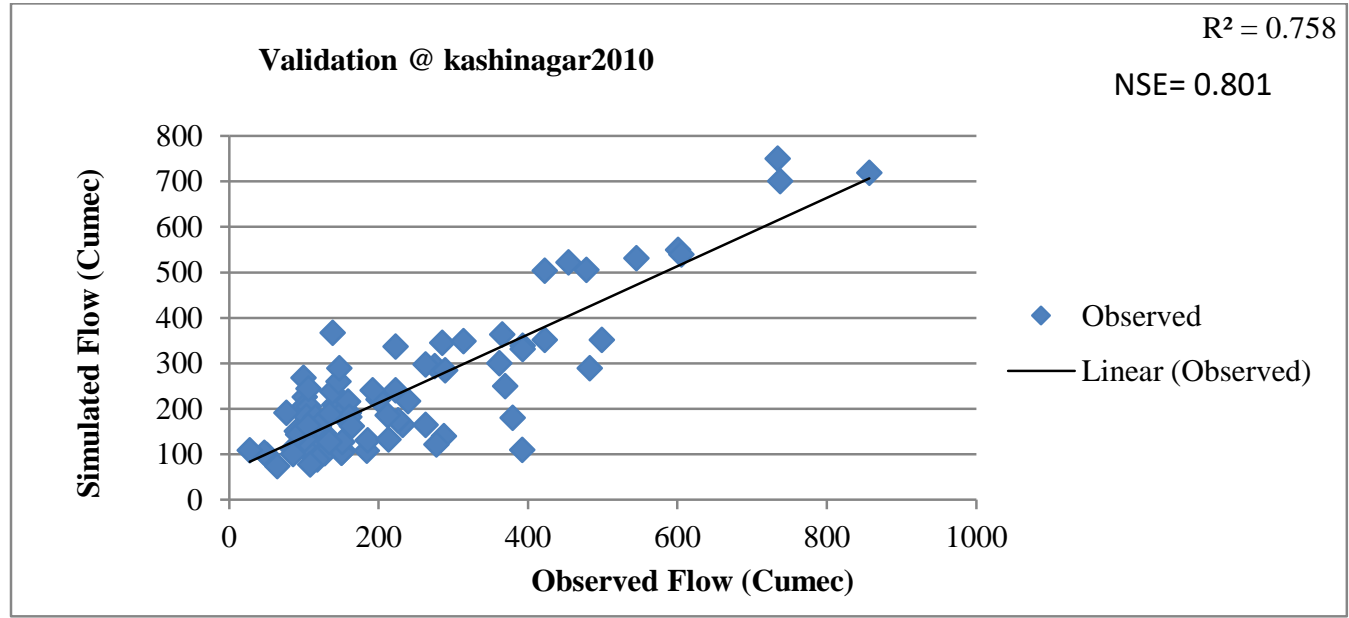

(b)

Figure 9 Scatter plot comparison between simulated \& observed flow for calibrated year 2010 for Vamsadhara river (a) At Gunupur gauge station (b) At Kashinagar gauge station

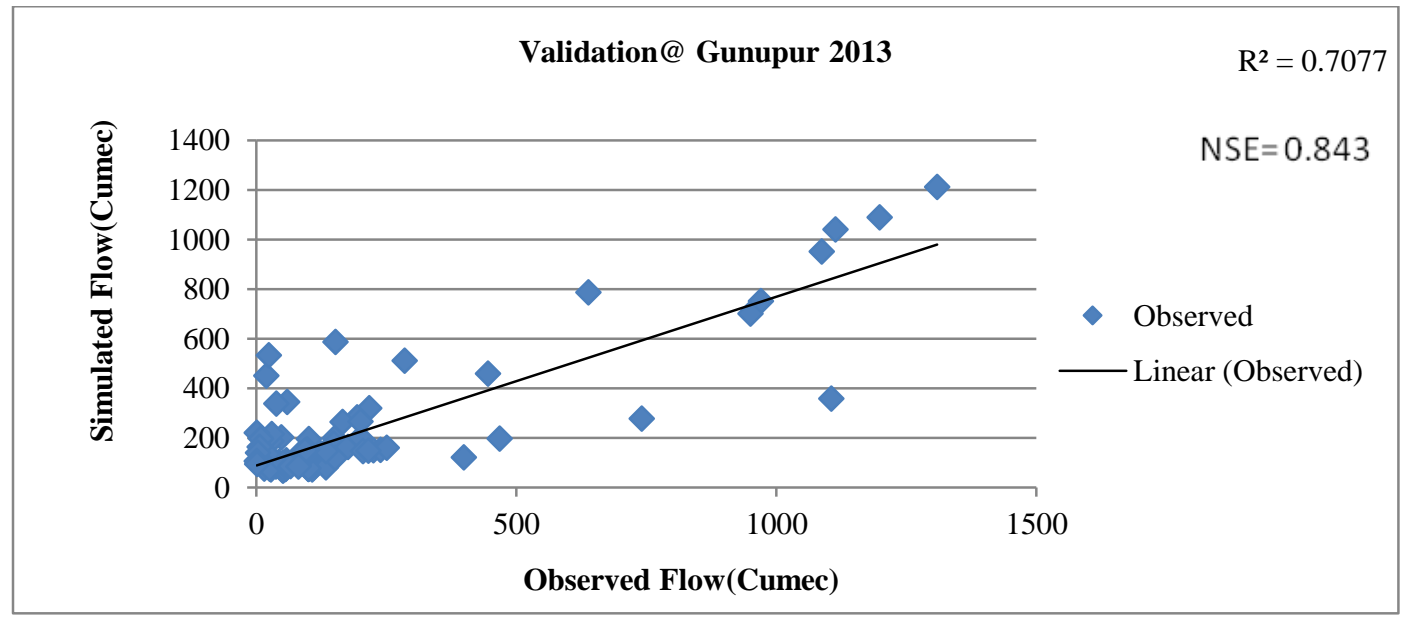

(a)

1072 
International Journal of Advanced Technology and Engineering Exploration, Vol 8(81)

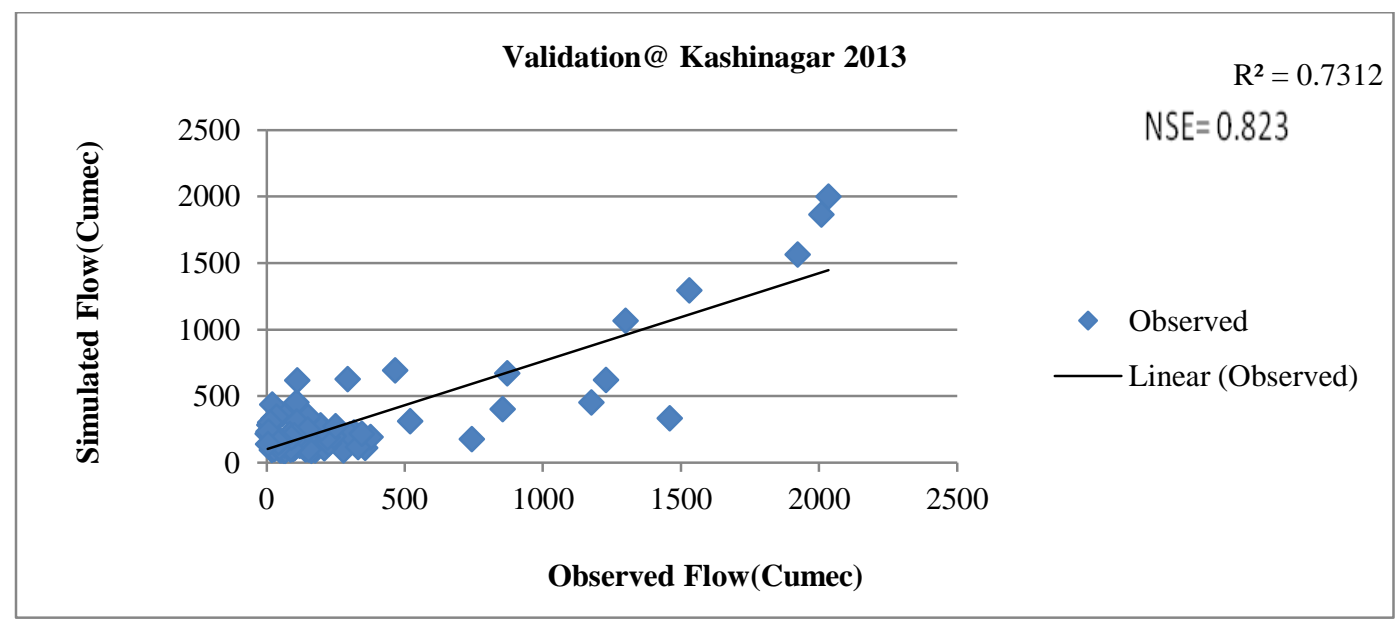

(b)

Figure 10 Scatter plot comparison between simulated \& observed flow for calibrated year 2013 for Vamsadhara river (a) At Gunupur gauge station (b) At Kashinagar gauge station

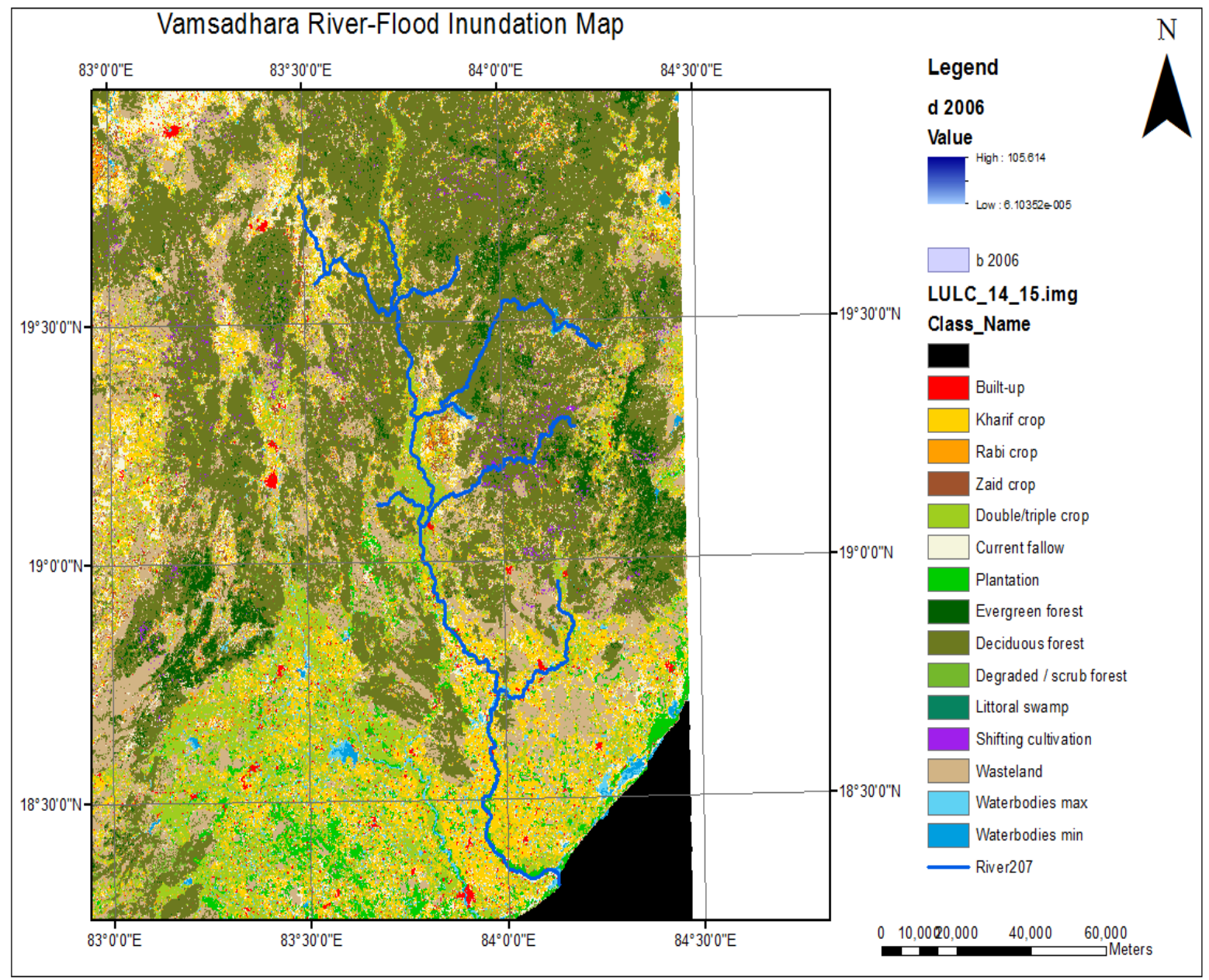

Figure 11 Flood inundation map during the cyclone, 2006 
Arunima Mahapatra et al.

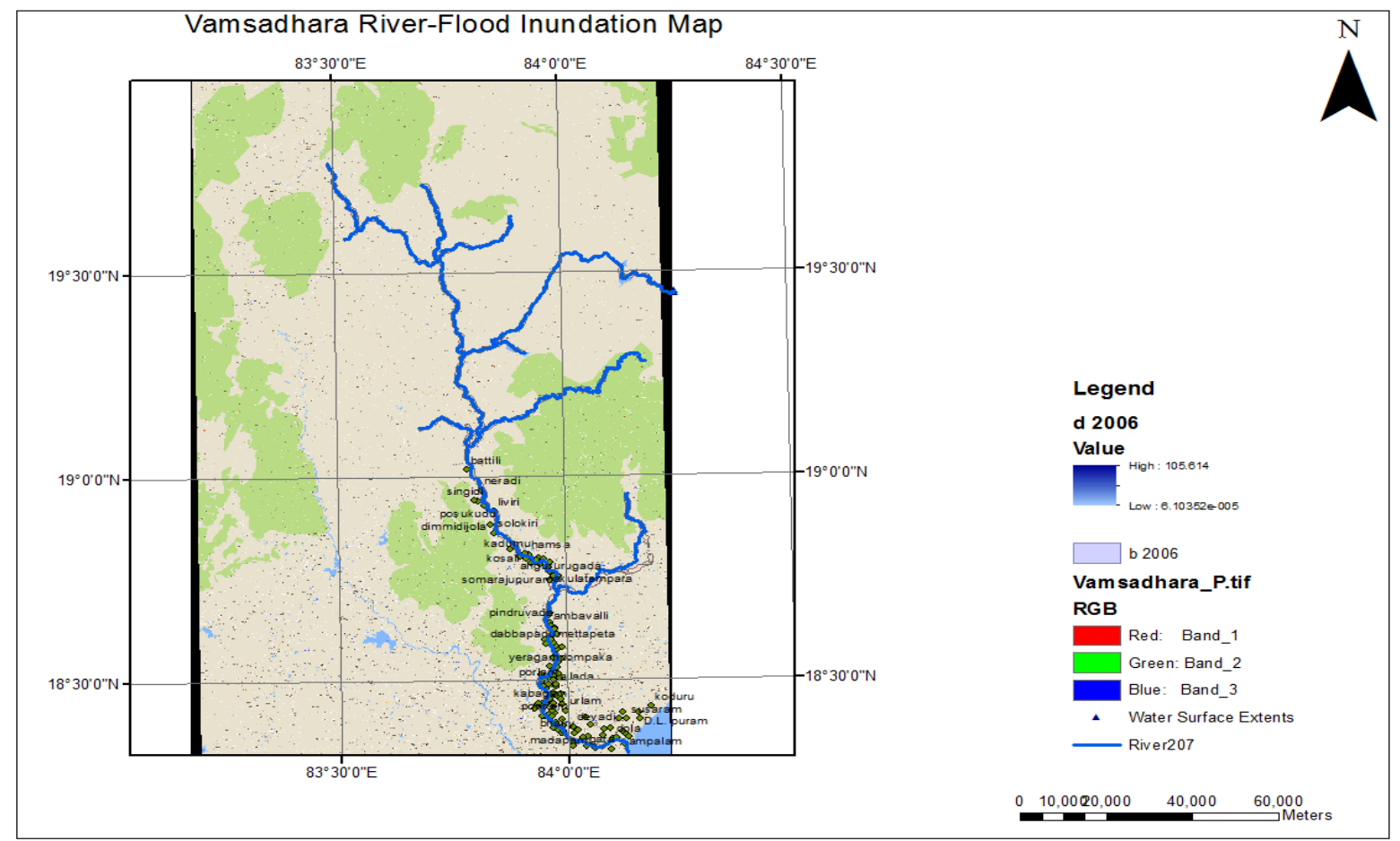

Figure 12 The villages inundated in AP state during the selected floods in Vamsadhara River are identified

Table 5 Villages inundated in Srikakulam district during the cyclone, 2006

\begin{tabular}{clcl}
\hline Object Id & Name & Object Id & Name \\
\hline 1 & Kajarada & 26 & Gollapeta \\
2 & Batteru & 27 & Andhavaram \\
3 & Ronanki & 28 & Ramakrishnapuram \\
4 & Bhairy & 29 & Achyutapuram \\
5 & Ponnam & 30 & Nagarikatakam \\
6 & Buravalli & 31 & Mettapeta \\
7 & Ambalavalasa & 32 & Srimukhalingam \\
8 & Salihundam & 33 & Suravaram \\
9 & Gara & 34 & Komanapalle \\
10 & Posukudu & 35 & Yatapeta \\
11 & Neradi & 36 & Mahalakshmipurm \\
12 & Nivagam & 37 & Bhagirathipuram \\
13 & Vasapa & 38 & Pindruvada \\
14 & Hamsa & 39 & Ambavalli \\
15 & Kadumu & 40 & Rellivalasa \\
16 & Sirusuvada & 41 & Akkarapalle \\
17 & Kuntibadhra & 42 & Ramachandrapuram \\
18 & Somarajupuram & 43 & Chevakulapeta \\
19 & Matala & 44 & Ponnampeta \\
20 & Penugottivada & 45 & Lukulam \\
21 & V.N. Puram & 46 & Kameshwaripeta \\
22 & Akulatampara & 47 & Chennulavalasa \\
23 & Vadavalasa & 48 & Butchipeta \\
24 & Dabbapadu & 49 & Madapam \\
25 & Telikipenta & 50 & Geddavanipeta \\
\hline
\end{tabular}


Table 6 Villages inundated in Srikakulam district during the cyclone Phailin, 2013

\begin{tabular}{|c|c|c|c|c|c|}
\hline ID & Name & ID & Name & ID & Name \\
\hline 1 & Kajarada & 27 & Yeragam & 53 & Ponnampeta \\
\hline 2 & Batteru & 28 & PeddaSavalapuram & 54 & Lukulam \\
\hline 3 & Ronanki & 29 & Dola & 55 & Kameshwaripeta \\
\hline 4 & Bhairy & 30 & Pallipeta & 56 & Chennulavalasa \\
\hline 5 & Ponnam & 31 & Linganayudupeta & 57 & Butchipeta \\
\hline 6 & Buravalli & 32 & Udakalapeta & 58 & Madapam \\
\hline 7 & Ambalavalasa & 33 & Dompaka & 59 & Geddavanipeta \\
\hline 8 & Salihundam & 34 & Porlam & 60 & Muddadapeta \\
\hline 9 & Gara & 35 & Gollapeta & 61 & Kabagam \\
\hline 10 & Posukudu & 36 & Andhavaram & 62 & Venkatapuram \\
\hline 11 & Neradi & 37 & Ramakrishnapuram & 63 & Ambajipeta \\
\hline 12 & Nivagam & 38 & Achyutapuram & 64 & Gopalapenta \\
\hline 13 & Vasapa & 39 & Nagarikatakam & 65 & Anguru \\
\hline 14 & Hamsa & 40 & Mettapeta & 66 & Rugada \\
\hline 15 & Kadumu & 41 & Srimukhalingam & 67 & Chodavaram \\
\hline 16 & Sirusuvada & 42 & Suravaram & 68 & Allada \\
\hline 17 & Kuntibadhra & 43 & Komanapalle & 69 & Ramadasupeta \\
\hline 18 & Somarajupuram & 44 & Yatapeta & 70 & Gangammapeta \\
\hline 19 & Matala & 45 & Mahalakshmipuram & 71 & Ampalam \\
\hline 20 & Penugottivada & 46 & Bhagirathipuram & 72 & Nandigam \\
\hline 21 & V.N. Puram & 47 & Pindruvada & 73 & Narasinghanaidupeta \\
\hline 22 & Akulatampara & 48 & Ambavalli & 74 & Kottapalavalasa \\
\hline 23 & Vadavalasa & 49 & Rellivalasa & 75 & Anandapuram \\
\hline 24 & Dabbapadu & 50 & Akkarapalle & 76 & Kollavanipeta \\
\hline 25 & Telikipenta & 51 & Ramachandrapuram & & \\
\hline 26 & Sivaramapuram & 52 & Chevakulapeta & & \\
\hline
\end{tabular}

\section{Conclusion}

The study's primary aim is to develop a semidistributed model for the Vamsadhara river basin. Further, the HEC-HMS model was calibrated and validated for two years using real-time historic flood events. In the study SCS loss method, SCS-UH, Muskingum routing methods were found to be very effective in calculating flood discharge in a sub-basin. The simulated peak discharge of the Vamsadhara catchment was slightly over predicted than the observed flow this variation in discharge values is due to differences in mean rainfall, geologic formation, slope, travel time, vegetation cover, and land use in the sub-basins. Model accuracy and performance still can further be improved by subdividing into more subbasins [53].

Following are some of the specific conclusions from the analysis:

- Flood Hydrographs for flood events 2006, 2010 \& 2013 showed that the model calibrated and validated illustrates a close agreement with the computed and observed flow in terms of timing of peak, peak flow, and volume of flow.

- Reasonable results were obtained for the semi distributed model with efficiency $78.6 \%$ for the calibration period (2006) and nearly $81.2 \%, 84.3 \%$ for the validation period ( $2010 \& 2013)$.

- The model outputs i.e., the difference in total runoff volume resulted from the two flood events (validated) is within $\pm 20 \%$ acceptance level for the modeling process Bingner et al. [68]

- The Muskingum parameters $\mathrm{K}$ and x calculated can be considered for accurate

- The Flood inundation maps generated from the present GIS modeling are also validated and the output maps generated are sufficiently accurate.

Though the structure of HEC-HMS is simple, it is a highly effective tool for flood forecasting. The above values obtained for the model are acceptable. This study also finds that, as it is a real-time hydrological model, it may be applied to other minor catchments in the Vamsadhara river basin as operational flood forecasting in monitoring floods and minimizing natural hazards to a certain extent.

\section{Future scope}

Future researchers may be able to expand their knowledge of flood modeling and develop the twodimensional unsteady flow analysis. 


\section{Acknowledgment}

We would like to convey our heartfelt appreciation to the Director of Flood Forecasting \& Hydrological Modeling Division, Water Resources Group, National Remote Sensing Centre (NRSC), Hyderabad, for supplying us with the LULC, DEM, Satellite, and Rainfall grid data. We are also grateful to the CWC, Bhubaneswar, Odisha, for supplying us with the Vamsadhara River basin stage and gauge discharge data.

\section{Conflicts of interest}

The authors have no conflicts of interest to declare.

\section{References}

[1] Bhatt JR, Sharma SK. Impacts of climate change on India and climate change related activities. Tata McGraw-Hill Publishing Companay Ltd, New Delhi; 2002.

[2] Markus M, Angel JR, Yang L, Hejazi MI. Changing estimates of design precipitation in Northeastern Illinois: comparison between different sources and sensitivity analysis. Journal of Hydrology. 2007; 347(12):211-22

[3] https://library.wmo.int/index.php?lvl=notice_display\& id=5841\#. YSx5nfozbIU. Accessed 26 October 2020.

[4] Matkan A, Shakiba A, Pourali H, Azari H. Flood early warning with integration of hydrologic and hydraulic models, RS and GIS (Case Study: Madarsoo Basin, Iran). World Applied Sciences Journal. 2009; 6(12):1698-704.

[5] Rao KH, Rao VV, Dadhwal VK, Behera G, Sharma JR. A distributed model for real-time flood forecasting in the Godavari Basin using space inputs. International Journal of Disaster Risk Science. 2011; 2(3):31-40.

[6] Morin E, Jacoby Y, Navon S, Bet-halachmi E. Towards flash-flood prediction in the dry Dead Sea region utilizing radar rainfall information. Advances in Water Resources. 2009; 32(7):1066-76.

[7] https://www.hec.usace.army.mil/software/hechms/documentation/HEC-

HMS_Users_Manual_4.2.pdf. Accessed 26 October 2020 .

[8] Feldman AD. Hydrologic modeling system HEC-HMS . Technical Reference Manual. 2000.

[9] Majidi A, Shahedi K. Simulation of rainfall-runoff process using Green-ampt method and HEC-HMS model (Case study: Abnama Watershed, Iran). International Journal of Hydraulic Engineering. 2012; 1(1):5-9.

[10] Choudhari K, Panigrahi B, Paul JC. Simulation of rainfall-runoff process using HEC-HMS model for Balijore Nala watershed, Odisha, India. International Journal of Geomatics and Geosciences. 2014; 5(2):25365.

[11] Kabiri R. Simulation of runoff using modified SCS-CN method using GIS system, case study: klang watershed in Malaysia. Research Journal of Environmental Sciences. 2014; 8(4):178-92.
[12] https://sandrp.in/2017/05/23/rivers-profile-of-andhrapradesh-and-telangana-states/. Accessed 26 October 2020.

[13] https://www.researchgate.net/publication/274703806 Inter_and_Transdisciplinary_Research_Methods_in_R ural_Transformation_Case_studies_in_Northern_Ethi opia. Accessed 26 October 2020.

[14] Jakeman AJ, Hornberger GM. How much complexity is warranted in a rainfall-runoff model? Water Resources Research. 1993; 29(8):2637-49.

[15] Sahour H, Mokhtari A, Ghahfarokh SS. Rainfall-runoff modeling using remotely sensed data and the hydrologic modeling system (HEC-HMS). Eco. Env. \& Cons. 2016; 22(4):163-73.

[16] Solaimani K. GIS-based multidate flood forecasting using hydraulic model. International Journal of Physical Sciences. 2011; 6(3):577-82.

[17] Shehata M, Mizunaga H. Geospatial analysis of surface hydrological parameters for Kyushu Island, Japan. Natural Hazards. 2019; 96(1):33-52.

[18] Abdelkarim A, Gaber AF, Alkadi II, Alogayell HM Integrating remote sensing and hydrologic modeling to assess the impact of land-use changes on the increase of flood risk: a case study of the Riyadh-Dammam train track, Saudi Arabia. Sustainability. 2019; 11(21):1-32.

[19] Sarminingsih A, Rezagama A. Simulation of rainfallrunoff process using HEC-HMS model for garang watershed, semarang, Indonesia. In journal of physics: conference series 2019 (pp.1-9). IOP Publishing.

[20] Othman N, Romali NS, Samat SR, Ahmad AM. Calibration and validation of hydrological model using HEC-HMS for Kuantan River Basin. In IOP conference series: materials science and engineering 2021 (pp.1-6). IOP Publishing.

[21] De SMM, Weerakoon SB, Herath S. Modeling of event and continuous flow hydrographs with HEC-HMS: case study in the Kelani River Basin, Sri Lanka. Journal of Hydrologic Engineering. 2014; 19(4):800-6.

[22] Msaddek M, Kimbowa G, El GA. Hydrological modeling of upper oumerrabia basin (Morocco), comparative study of the event-based and continuousprocess HEC-HMS model methods. Computational Water, Energy, and Environmental Engineering. 2020; 9(4):159-84.

[23] Mccoll C, Aggett G. Land-use forecasting and hydrologic model integration for improved land-use decision support. Journal of Environmental Management. 2007; 84(4):494-512.

[24] Du J, Qian L, Rui H, Zuo T, Zheng D, Xu Y, et al. Assessing the effects of urbanization on annual runoff and flood events using an integrated hydrological modeling system for Qinhuai River Basin, China. Journal of Hydrology. 2012; 464:127-39.

[25] Knebl MR, Yang ZL, Hutchison K, Maidment DR. Regional scale flood modeling using NEXRAD rainfall, GIS, and HEC-HMS/RAS: a case study for the San Antonio River Basin summer 2002 storm event. Journal of Environmental Management. 2005; 75(4):325-36. 
[26] Li S, Qi R, Jia W. Calibration of the conceptual rainfallrun off model's parameters. In advances in water resources and hydraulic engineering 2009 (pp. 55-9). Springer, Berlin, Heidelberg.

[27] Khakbaz B, Imam B, Hsu K, Sorooshian S. From lumped to distributed via semi-distributed: calibration strategies for semi-distributed hydrologic models. Journal of Hydrology. 2012; 418:61-77.

[28] Aghakouchak A, Habib E. Application of a conceptual hydrologic model in teaching hydrologic processes. International Journal of Engineering Education. 2010; 26(4):963-73.

[29] Oleyiblo JO, Li ZJ. Application of HEC-HMS for flood forecasting in Misai and Wan'an catchments in China. Water Science and Engineering. 2010; 3(1):14-22.

[30] Yener MK, Sorman AU, Sorman AA, Sensoy A, Gezgin T. Modeling studies with HEC-HMS and runoff scenarios in Yuvacik Basin, Turkiye. International Congress on River Basin Manage. 2007; 4:621-34.

[31] Prabha JA, Tapas MR. Event-based rainfall-runoff modeling using HEC-HMS. IOSR Journal of Mechanical and Civil Engineering. 2020; 17(4):41-59.

[32] Fleming M, Neary V. Continuous hydrologic modeling study with the hydrologic modeling system. Journal of Hydrologic Engineering. 2004; 9(3):175-83.

[33] Singh VP, Woolhiser DA. Mathematical modeling of watershed hydrology. Journal of Hydrologic Engineering. 2002; 7(4):270-92.

[34] Yusop Z, Chan CH, Katimon A. Runoff characteristics and application of HEC-HMS for modelling stormflow hydrograph in an oil palm catchment. Water Science and Technology. 2007; 56(8):41-8.

[35] Ali M, Khan SJ, Aslam I, Khan Z. Simulation of the impacts of land-use change on surface runoff of Lai Nullah Basin in Islamabad, Pakistan. Landscape and Urban Planning. 2011; 102(4):271-9.

[36] Zelelew DG, Langon S. Selection of appropriate loss methods in HEC-HMS model and determination of the derived values of the sensitive parameters for ungauged catchments in Northern Ethiopia. International Journal of River Basin Management. 2020; 18(1):12735.

[37] Halwatura D, Najim MM. Application of the HECHMS model for runoff simulation in a tropical catchment. Environmental Modelling \& Software. 2013; 46:155-62.

[38] Azam M, San KH, Maeng SJ. Development of flood alert application in Mushim stream watershed Korea. International Journal of Disaster Risk Reduction. 2017; 21:11-26.

[39] Visweshwaran R. Application of the HEC-HMS model for runoff simulation in the Krishna Basin. Master's Thesis, National Institute of Technology Karnataka, Surathkal, India. 2017.

[40] Derdour A, Bouanani A, Babahamed K. Modelling rainfall runoff relations using HEC-HMS in a semi-arid region: case study in Ain Sefra watershed, Ksour Mountains (SW Algeria). Journal of Water and Land Development. 2018; 36:45-55.
[41] Vaishnava S. Characteristics of hydrological modelling of mahanadi basin using the hec-hms software (Doctoral Dissertation). Delhi Technological University. 2020.

[42] Goodell C, Warren C. Flood inundation mapping using HEC-RAS. Obras Y Proyectos. 2006; 2:18-23.

[43] Forkuo EK. Flood hazard mapping using Aster image data with GIS. International Journal of Geomatics and Geosciences. 2011; 1(4):932-50.

[44] Mehta DJ, Ramani MM, Joshi MM. Application of 1-D HEC-RAS model in design of channels. International Journal of Innovative Research in Advanced Engineering. 2013; 1(7):103-7.

[45] Abdessamed D, Abderrazak B. Coupling HEC-RAS and HEC-HMS in rainfall-runoff modeling and evaluating floodplain inundation maps in arid environments: case study of Ain Sefra city, Ksour Mountain. SW of Algeria. Environmental Earth Sciences. 2019; 78(19):1-7.

[46] Icyimpaye G, Abdelbaki C, Mourad KA. Hydrological and hydraulic model for flood forecasting in Rwanda. Modeling Earth Systems and Environment. 2021.

[47] Agarwal A, Rai RK, Upadhyay A. Forecasting of runoff and sediment yield using artificial neural networks. Journal of Water Resource and Protection. 2009; 1(5):368-75.

[48] Gann D. Rainfall estimation raster conversion data preparation for hydrological modeling with SWAT Mara Basin (Kenya/Tanzania). GIS- RS Center Florida International University. 2007.

[49] http://cwc.gov.in/sites/default/files/Combined\%20Fina 1_HDD_09042012.pdf. Accessed 26 October 2020.

[50] Eadara A, Karanam H. Slope studies of Vamsadhara River Basin: a quantitative approach. International Journal of Engineering and Innovative Technology. 2013; 3(1):184-9.

[51] http://cgwb.gov.in/District_Profile/Orissa/Koraput.pdf . Accessed 26 October 2020.

[52] Agarwal A, Singh RD, Mishra SK, Bhunya PK. ANNbased sediment yield models for Vamsadhara river Basin (India). Water Sa. 2005; 31(1):85-100.

[53] Hromadka TV, Mccuen RH, Yen CC. Effect of watershed subdivision on prediction accuracy of hydrologic models. Hydrosoft. 1988; 1(1):19-28.

[54] Sardoii ER, Rostami N, Sigaroudi SK, Taheri S. Calibration of loss estimation methods in HEC-HMS for simulation of surface runoff (Case Study: Amirkabir Dam Watershed, Iran). Advances in Environmental Biology. 2012; 6(1):343-8.

[55] Mccuen RH. Review of curve number hydrology: state of the practice by RH hawkins, TJ Ward, DE Woodward, and JA Van Mullem: ASCE, Reston, VA.

[56] Cronshey R. Urban hydrology for small watersheds. US Department of Agriculture, Soil Conservation Service, Engineering Division; 1986.

[57] Patil VK, Saraf VR, Karad OV, Ghodke SB, Gore D, Dhekale SS. Simulation of rainfall runoff process using HEC-HMS model for upper Godavari Basin Maharashtra, India. European Journal of Engineering and Technology Research. 2019; 4(4):102-7. 
[58] Reddy NA, Seelam JK, Rao S, Nagaraj MK. Flood estimation at ungauged catchments of western catchments of Karnataka, West Coast of India. ISH Journal of Hydraulic Engineering. 2019; 25(3):325-35.

[59] Mccarthy GT. The unit hydrograph and flood routing. In proceedings of conference of North Atlantic division, US army corps of engineers 1938 (pp. 608-9).

[60] Tewolde MH, Smithers JC. Flood routing in ungauged catchments using muskingum methods. Water Sa. 2006; 32(3):379-88.

[61] Brunner GW. HEC-RAS hydraulic reference manual. Davis: US Army Corps of Engineers, Hydrologic Engineering Center. 2001.

[62] Moriasi DN, Arnold JG, Van LMW, Bingner RL, Harmel RD, Veith TL. Model evaluation guidelines for systematic quantification of accuracy in watershed simulations. Transactions of the ASABE. 2007; 50(3):885-900.

[63] Nash JE, Sutcliffe JV. River flow forecasting through conceptual models part I-a discussion of principles. Journal of Hydrology. 1970; 10(3):282-90.

[64] Tahmasbinejad H, Feyzolahpour M, Mumipour M, Zakerhoseini F. Rainfall-runoff simulation and modeling of Karun river using HEC-RAS and HECHMS models, Izeh District, Iran. Journal of Applied Sciences. 2012; 12(18):1900-8.

[65] Lin M, Chen X, Chen Y, Yao H. Improving calibration of two key parameters in hydrologic engineering center hydrologic modelling system, and analysing the influence of initial loss on flood peak flows. Water Science and Technology. 2013; 68(12):2718-24.

[66] Cunderlik J, Simonovic SP. Calibration, verification and sensitivity analysis of the HEC-HMS hydrologic model. Department of Civil and Environmental Engineering, The University of Western Ontario; 2004.

[67] Sabzevari T, Ardakanian R, Shamsaei A, Talebi A. Predicting the flood hydrographs of ungauged watersheds using the HEC-HMS model and the geographic information system (GIS)(Case Study: Kasilian Watershed). Water Engineering, 2009; 2(4):111.

[68] Bingner RL, Murphree CE, Mutchler CK. Comparison of sediment yield models on watersheds in Mississippi. Transactions of the ASAE. 1989; 32(2):529-34.

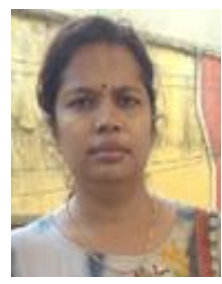

Arunima Mahapatra is a research scholar at Andhra University working on her $\mathrm{PhD}$ part-time. In addition, she is currently working as Assistant Professor at Dr. Lankapalli Bullayya College of Engineering in Visakhapatnam. She received her B.E (Civil) from GITAM and her M.Tech (RS \& GIS) from

Andhra University. She has ten years of teaching experience. She has papers published in two international journals as well as three conference proceedings. She is a member of the Indian Society of Hydraulics (ISH) and the Indian Society of Geomatics (ISG).

Email: arunimamahapatra162@gmail.com

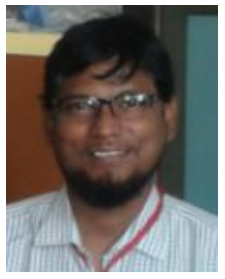

Dr. Vazeer Mahammood is a professor of Civil Engineering in Andhra University. Currently he is serving as Head of the Department in GeoEngineering. He previously served as Assistant Principal of AUCOE during 2008-2010. He also rendered his services as a Deputy Director of the Regional Centre for Educational Development of Minorities for A.P state Government. He held the position of Associate director, A.U. Admissions, during 2013-2017. Since 2017 he has been assigned as Dean (Engineering Works). Currently he is playing an active role in a smart city development programme of Government of India for Visakhapatnam city as an independent director. He is a leading civil engineering consultant Government \& Private agencies. He earned a B.Tech from Acharya Nagarjuna University, M.E (Hydraulics, Coastal \& Harbour Engineering) from A.U, M.Tech (RS\& GIS) from Centre for space science \& Technology for Asia and the Pacific (Affiliated to United Nations), M.E (Structures) from A.U, and awarded PhD in 2005 from A.U. He has over 30 publications in national and international journals and conferences. Four students have successfully completed their PhDs under his supervision, and seven more are in various stages of completion. He has completed two UGC-funded major research projects and also completed a minor research project in collaboration with the NRSC, Hyderabad. He is a member of several professional organizations, including the Institute of Engineers, the Indian Society of Hydraulics, the Indian Society for Remote Sensing, and the Indian Society of Geomatics (ISG). His current research interests include the Coastal structures and the application of remote sensing and geographic information systems to the fields of 1) watershed management. 2) Lake and reservoir environmental studies 3) Modeling of hydrological systems.

Email: vazir81c158@gmail.com

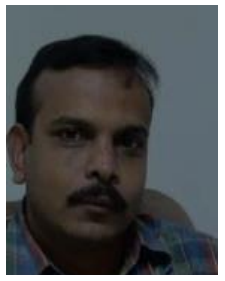

Dr. K H V Durga Rao currently works as Group Head, Disaster Management Support Group of National Remote Sensing Centre (NRSC), Indian Space Research Organization. He is a scientist in NRSC \& ISRO with an experience of more than 18 years. He had done his B.E (Civil ) at Andhra University, M.Tech (IIT Kharagpur) and PhD Andhra University. He has over 29 publications in national and international journals and conferences. He does research in Hydrological modelling, flood early warning, spatial flood inundation modelling, Flood Vulnerability \& Risk Assessment, and Disaster Risk Reduction.

Email: durgarao_khv@nrsc.gov.in 


\begin{tabular}{|c|c|c|}
\hline \multicolumn{3}{|c|}{ Appendix I } \\
\hline S.No & Abbreviation & Description \\
\hline 1 & $1 \mathrm{D}$ & One Dimensional \\
\hline 2 & CWC & Central Water Commission \\
\hline 3 & DEM & Digital Elevation Model \\
\hline 4 & GCS-WGS84 & $\begin{array}{ll}\text { Geographic Coordinates } & \text { System- } \\
\text { World Geodetic System84 } & \end{array}$ \\
\hline 5 & GIS & Geographic Information System \\
\hline 6 & HEC-HMS & $\begin{array}{l}\text { Hydrologic Engineering Centre 's } \\
\text { Hydrologic Modelling System }\end{array}$ \\
\hline 7 & HEC-RAS & $\begin{array}{l}\text { Hydrologic Engineering Centre 's } \\
\text { River Analysis System }\end{array}$ \\
\hline 8 & LISS-III & $\begin{array}{l}\begin{array}{l}\text { Linear } \\
\text { Sensor }\end{array} \\
\end{array}$ \\
\hline 9 & LULC & Land Use Land Cover \\
\hline 10 & NBSS \& LUP & $\begin{array}{l}\text { The National Bureau of Soil Science } \\
\& \text { Land Use Planning }\end{array}$ \\
\hline 11 & NRSC & National Remote Sensing Centre \\
\hline 12 & NSE & Nash-Sutcliffe Model Efficiency \\
\hline 13 & $\mathrm{R}^{2}$ & Coefficient of Determination \\
\hline 14 & SCS-CN & $\begin{array}{l}\text { The Soil Conservation Service- } \\
\text { Curve Number }\end{array}$ \\
\hline 15 & SCS-UH & $\begin{array}{l}\text { The Soil Conservation Service- Unit } \\
\text { Hydrograph }\end{array}$ \\
\hline 16 & SANDRP & $\begin{array}{l}\text { South Asia Network on Dams, } \\
\text { Rivers and People }\end{array}$ \\
\hline 17 & SRTM & Shuttle Radar Topography Mission \\
\hline 18 & TIN & Triangular Irregular Networks \\
\hline 19 & USDA & $\begin{array}{lll}\begin{array}{l}\text { United States } \\
\text { Agriculture }\end{array} & \text { Department } & \text { Of } \\
\end{array}$ \\
\hline 20 & USACE & $\begin{array}{l}\text { United States Army Corps of } \\
\text { Engineers }\end{array}$ \\
\hline 21 & UTM & Universal Transverse Mercator \\
\hline
\end{tabular}

